$5-1993$

\title{
Archeological Survey and Monitoring of JTF-6 Road Improvements, Sierra Blanca, Hudspeth County, Texas
}

Sheridan K. Edwards

Geo-Marine, Inc.

Duane E. Peter

Follow this and additional works at: https://scholarworks.sfasu.edu/ita

Part of the American Material Culture Commons, Archaeological Anthropology Commons, Environmental Studies Commons, Other American Studies Commons, Other Arts and Humanities Commons, Other History of Art, Architecture, and Archaeology Commons, and the United States History Commons

Tell us how this article helped you.

This Article is brought to you for free and open access by the Center for Regional Heritage Research at SFA ScholarWorks. It has been accepted for inclusion in Index of Texas Archaeology: Open Access Gray Literature from the Lone Star State by an authorized editor of SFA ScholarWorks. For more information, please contact cdsscholarworks@sfasu.edu. 
Archeological Survey and Monitoring of JTF-6 Road Improvements, Sierra Blanca, Hudspeth County, Texas

Creative Commons License

(c) (1) $\Theta($

This work is licensed under a Creative Commons Attribution-NonCommercial-No Derivative Works 4.0 International License. 


\begin{tabular}{|c|c|c|c|c|c|}
\hline \multicolumn{4}{|c|}{ REPORT DOCUMENTATION PAGE } & \multicolumn{2}{|c|}{$\begin{array}{l}\text { Form Approved } \\
\text { OMB No. 0704-0188 }\end{array}$} \\
\hline \multicolumn{2}{|l|}{$\begin{array}{c}\text { 1a. REPORT SECURITY CLASSIFICATION } \\
\text { Unclassified }\end{array}$} & \multicolumn{4}{|c|}{ 1b. RESTRICTIVE MARKINGS } \\
\hline \multicolumn{2}{|l|}{ 2a. SECURITY CLASSIFICATION AUTHORITY } & \multicolumn{4}{|c|}{$\begin{array}{l}\text { 3. DISTRIBUTIONAVAILABILITY OF REPORT } \\
\text { Approved for public release }\end{array}$} \\
\hline \multicolumn{2}{|c|}{ 4. PERFORMING ORGANIZATION REPORT NUMBERS } & \multicolumn{4}{|c|}{ 5. MONITORING ORGANIZATION REPORT NUMBER(S) } \\
\hline $\begin{array}{l}\text { 6a. NAME OF PERFORMING ORGANIZATION } \\
\text { Geo-Marine Inc. }\end{array}$ & $\begin{array}{l}\text { 6b. OFFICE SYMBOL } \\
\text { (if applicable) }\end{array}$ & \multicolumn{4}{|c|}{$\begin{array}{l}\text { 7a. NAME OF MONITORING ORGANIZATION } \\
\text { US Army Corps of Engineers, Fort Worth District }\end{array}$} \\
\hline \multicolumn{2}{|c|}{$\begin{array}{l}\text { 6c. ADDRESS (City, State, and Zip Code) I } \\
\qquad 550 \text { E. Fifteenth Street / Plano, Texas / } 75074\end{array}$} & \multicolumn{4}{|c|}{$\begin{array}{l}\text { 7b. ADDRESS (City, State, and Zip Code) } \\
\text { PO Box } 17300 \\
\text { Fort Worth, Texas } 76102\end{array}$} \\
\hline $\begin{array}{l}\text { 8a. NAME OF FUNDING/SPONSORING } \\
\text { ORGANIZATION } \\
\text { US Army Corps of Engineers, } \\
\text { Fort Worth District }\end{array}$ & $\begin{array}{l}\text { 8b. OFFICE SYMBOL } \\
\text { (if applicable) }\end{array}$ & \multicolumn{4}{|c|}{$\begin{array}{l}\text { 9. PROCUREMENT INSTRUMENT ID NUMBER } \\
\text { Contract No. DACA63-90-D-0061, Delivery Order No. } 27\end{array}$} \\
\hline \multirow{2}{*}{\multicolumn{2}{|c|}{ 8c. ADDRESS (City, State, and Zip Code) }} & \multicolumn{4}{|c|}{ 10. SOURCE OF FUNDING NUMBERS } \\
\hline & & $\begin{array}{l}\text { PROGRAM } \\
\text { ELEMENT NO. }\end{array}$ & $\begin{array}{l}\text { PROJECT } \\
\text { NO. }\end{array}$ & $\begin{array}{l}\text { TASK } \\
\text { NO. }\end{array}$ & $\begin{array}{l}\text { WORK UNIT } \\
\text { ACCESSION NO. }\end{array}$ \\
\hline
\end{tabular}

11. TITLE (Include Security Classification)

Archeological Survey and Monitoring of JTF-6 Road Improvements, Sierra Blanca, Hudspeth County, Texas

12a. PERSONAL AUTHOR(S)

Sherrian K. Edwards and Duane E. Peter

\begin{tabular}{|c|c|c|c|c|c|}
\hline \multicolumn{2}{|c|}{$\begin{array}{l}\text { 13a. TYPE OF REPORT } \\
\text { Final Report }\end{array}$} & \multicolumn{2}{|c|}{$\begin{array}{l}\text { 13b. TIME COVERED } \\
\text { FROM } 2 \text { 2/92 TO } 5 / 93\end{array}$} & $\begin{array}{l}\text { 14. DATE OF REPORT (Year, Month, Day) } \\
\text { May } 1993\end{array}$ & $\begin{array}{l}\text { 15. PAGE COUNT } \\
31\end{array}$ \\
\hline \multicolumn{6}{|c|}{ 16. SUPPLEMENTARY NOTATION } \\
\hline \multicolumn{3}{|c|}{ 17. COSATI CODES } & \multirow{3}{*}{\multicolumn{3}{|c|}{$\begin{array}{l}\text { 18. SUBJECT TERMS (Continue on reverse if necessary and identify by block number) } \\
\text { Archeology / Cultural Resources in Hudspeth County, Texas }\end{array}$}} \\
\hline FIELD & GROUP & SUB-GROUP & & & \\
\hline 05 & 06 & & & & \\
\hline
\end{tabular}

19. ABSTRACT (Continue on reverse if necessary and identify by block number)

This report presents the results of cultural resource survey and monitoring activities performed in conjunction with a Department of Defense Joint Task Force Six (JTF-6) project near Sierra Blanca in Hudspeth County, Texas. These cultural resource investigations were initiated by a request from the U.S. Border Patrol of Sierra Blanca, Texas for planned improvements to $50.3 \mathrm{~km}$ (31.25 miles) of existing roads. The goal was to improve the U.S. Border Patrol's effectiveness in monitoring and controlling the ongoing drug trafficking activities along the U.S.-Mexico International Border. The road repair and historic preservation efforts were coordinated by JTF-6, based at Fort Bliss, El Paso, Texas, and the U.S. Army Corps of Engineers, Fort Worth District.

Cultural resource survey and monitoring were tailored to focus on the areas to be disturbed by road repair activities and to identify cultural resource sites which were to be avoided during these activities. The survey and monitoring resulted in the recording of two prehistoric sites and 19 localities. The two sites, $41 \mathrm{HZ} 499$ and $41 \mathrm{HZ} 500$, exhibited a low density surface lithic scatter. Until the potential for subsurface deposits at these two sites is evaluated, both must be considered to be of "unknown" eligibility for nomination to the National Register of Historic Places. Therefore, it is recommended that these sites continue to be avoided until a final determination of their eligibility can be made through test excavations.

\begin{tabular}{l|l} 
20. DISTRIBUTION/AVAILABILITY OF ABSTRACT & 21. ABSTRACT SECURITY CLASSIFICATION
\end{tabular}

DUNCLASSIFIED/UNLIMITED $囚$ SAME AS RPT. $\square$ DTIC USERS

22a: NAME OF RESPONSIBLE INDIVIDUAL

Mr. Jay Newman

\section{Unclassified}

22b. TELEPHONE (Include Area Code) 817/334-3068 22c. OFFICE SYMBOL CESWF-PL-RC 


\title{
ARCHEOLOGICAL SURVEY AND MONITORING OF JTF-6 ROAD IMPROVEMENTS, SIERRA BLANCA, HUDSPETH COUNTY, TEXAS
}

\author{
by \\ Sherrian K. Edwards \\ Duane E. Peter \\ Principal Investigator: Duane E. Peter
}

Miscellaneous Report of Investigations No. 46

Prepared for:

U.S. Army Corp of Engineers

Fort Worth District

Prepared by:

Geo-Marine, Inc.

550 Fifteenth Street

Plano, Texas

May 1993 


\section{CONTRACT DOCUMENTATION}

The preparation of this document was accomplished under Contract No. DACA63-90-D-0061, Delivery Order No. 27, with the U.S. Army Corps of Engineers, Fort Worth District, P.O. Box 17300, Fort Worth, Texas 76102-0300. 


\section{MANAGEMENT SUMMARY}

This report presents the results of cultural resource survey and monitoring activities performed in conjunction with a Department of Defense Joint Task Force Six (JTF-6) project near Sierra Blanca in Hudspeth County, Texas. These cultural resource investigations were initiated by a request from the U.S. Border Patrol of Sierra Blanca, Texas for planned improvements to $50.3 \mathrm{~km}$ (31.25 miles) of existing roads. The goal was to improve the U.S. Border Patrol's effectiveness in monitoring and controlling the ongoing drug trafficking activities along the U.S.-Mexico International Border. The road repair and historic preservation efforts were coordinated by JTF-6, based at Fort Bliss, El Paso, Texas, and the U.S. Army Corps of Engineers, Fort Worth District.

Cultural resource survey and monitoring were tailored to focus on the areas to be disturbed by road repair activities and to identify cultural resource sites which were to be avoided during these activities. The survey and monitoring resulted in the recording of two prehistoric sites and 19 localities. The two sites, 41HZ499 and 41HZ500, exhibited a low density surface lithic scatter. Until the potential for subsurface deposits at these two sites is evaluated, both must be considered to be of "unknown" eligibility for nomination to the National Register of Historic Places. Therefore, it is recommended that these sites continue to be avoided until a final determination of their eligibility can be made through test excavations. 


\section{TABLE OF CONTENTS}

Management Summary $\ldots \ldots \ldots \ldots \ldots \ldots \ldots \ldots \ldots \ldots \ldots \ldots \ldots \ldots \ldots$

I. Introduction $\ldots \ldots \ldots \ldots \ldots \ldots \ldots \ldots \ldots \ldots \ldots \ldots \ldots \ldots \ldots$

II. $\quad$ Project Setting $\ldots \ldots \ldots \ldots \ldots \ldots \ldots \ldots \ldots \ldots \ldots \ldots \ldots \ldots \ldots$

Environmental Setting $\ldots \ldots \ldots \ldots \ldots \ldots \ldots \ldots \ldots$

Geology and Geomorphology ................... 4

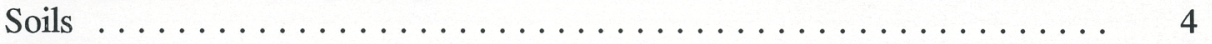

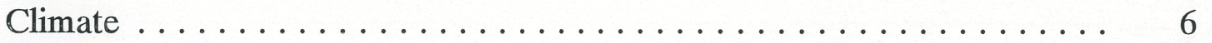

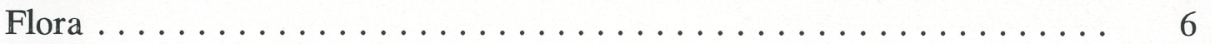

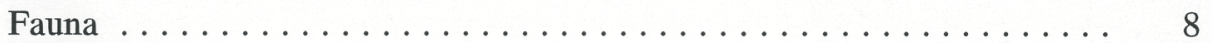

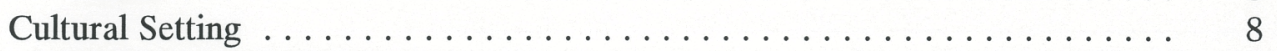

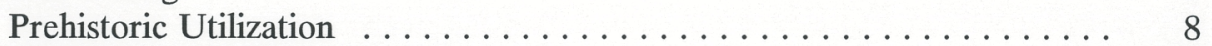

Historic Occupation . . . . . . . . . . . . . . . . . . . 13

Previous Archeological Investigations . . . . . . . . . . . . 16

III. $\quad$ Methodology $\ldots \ldots \ldots \ldots \ldots \ldots \ldots \ldots \ldots \ldots$

IV. Results and Recommendations ....................... 19

Survey Results . . . . . . . . . . . . . . . . . . . . . . 19

Recommendations ............................. 24

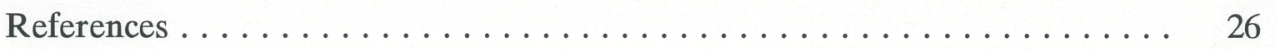




\section{LIST OF FIGURES}

No.

1. General survey area in West Texas $\ldots \ldots \ldots \ldots \ldots \ldots \ldots \ldots \ldots \ldots \ldots \ldots \ldots$

2. Route of pedestrian survey $\ldots \ldots \ldots \ldots \ldots \ldots \ldots \ldots \ldots \ldots \ldots$

3. Seven Major Vegetation Zones in the Trans-Pecos Region $\ldots \ldots \ldots \ldots \ldots$

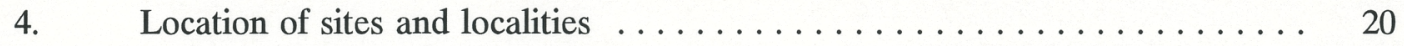

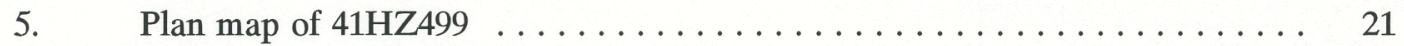

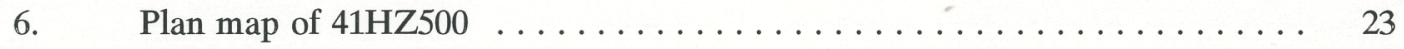

\section{LIST OF TABLES}

No. $\quad \underline{\text { Page }}$

1. Water-bearing Characteristics of Geologic Units that are Significant

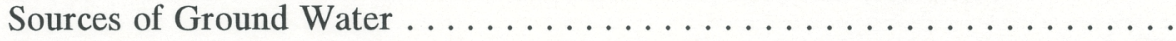




\section{CHAPTER 1}

\section{INTRODUCTION}

This report is the result of archeological survey and monitoring carried out to evaluate the possible cultural resources impacted by proposed road improvements around the city of Sierra Blanca, Texas (Figure 1). The U.S. Border Patrol has proposed improvements to $50.3 \mathrm{~km}$ (31.25 miles) of roads, located on both private and State lands, to enhance enforcement in the areas of drug trafficking and illegal immigration into the United States. The construction is being coordinated by Department of Defense Joint Task Force Six (JTF-6). The survey area is located north of I-10 and west of Texas Road 1111 in Hudspeth County. The present-day dirt roads have deteriorated through daily use and extensive erosion. The proposed road construction will improve the condition of these existing roads and make them passable in all types of weather conditions by means of grading, filling, and earth moving.

An archeological assessment of the potential impact of the proposed road construction is required for partial fulfillment of Department of Defense obligations under the National Historical Preservation Act of 1966, as amended (PL-96-515); the Archeological and Historical Preservation Act of 1974, as amended (PL-93-291); the National Environmental Policy Act of 1969 (PL-90-190); Executive Order \#11593 "Protection and Enhancement of the Cultural Environment"; and Army Regulation (AR) 200-2, "Environmental Effect of Army Actions.

The initial plan consisted of a survey of $42.7 \mathrm{~km}$ of roads to evaluate the potential impacts of road improvements on the cultural resources. The investigation was under the direction of Duane E. Peter (Principal Investigator) and a pedestrian survey of the proposed route of road improvements was conducted February 25 to 28, 1992. Two prehistoric sites and 19 localities were located. The work was carried out by Sherrian K. Edwards (Field Supervisor), Elizabeth Mitchell, Gary Shaw, and Frank Winchell.

The second phase of the project involved monitoring the road repair of the majority of the previously surveyed roads $(42.7 \mathrm{~km})$ plus the survey and monitoring of an additional $7.6 \mathrm{~km}$ of roads within the project area. The need to improve the durability of the roads resulted in one section being rerouted. This rerouted portion shifted the road from a sandy valley floor, where it was subjected to intense erosion from runoff, onto a higher and more stable rock base (Figure 2). Although no new sites were encountered, two additional localities were recorded.

The monitoring and additional survey was carried out March 31 to April 22 by Sherrian K. Edwards (Field Supervisor) and Gary Shaw. The road improvements were carried out by the 37th Engineering Battalion, Bravo Company, Light Equipment Platoon stationed at Fort Bragg, North Carolina.

This report presents the findings of the survey and monitoring phases carried out in relation to the Sierra Blanca Border Road improvements. Chapter 2 provides the environmental and cultural setting of the region. The methodology used to systematically investigate the area is presented in Chapter 3. The results of the survey and monitoring, site specifications, and recommendations are discussed in Chapter 4. 


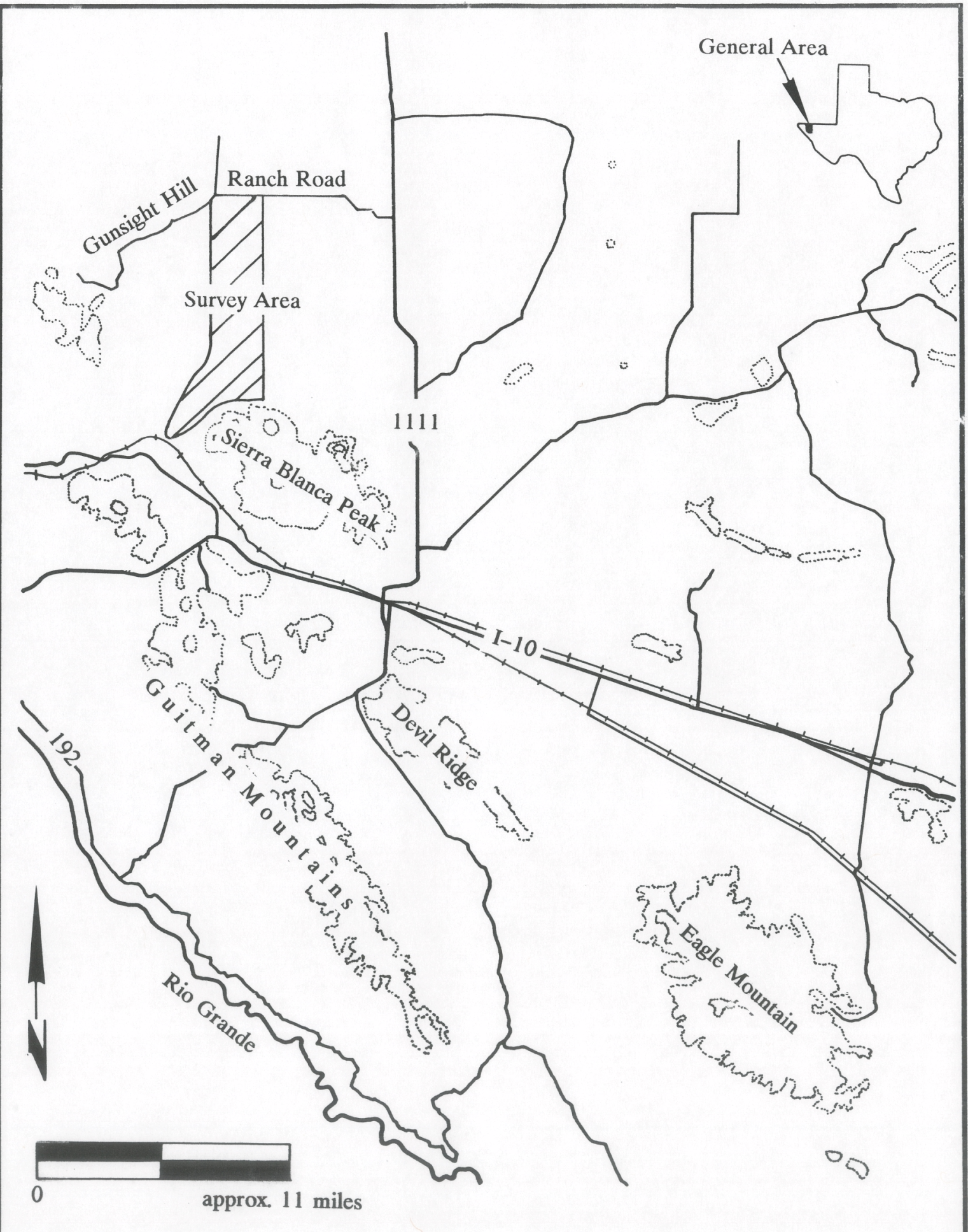

Figure 1: General survey area in West Texas. 


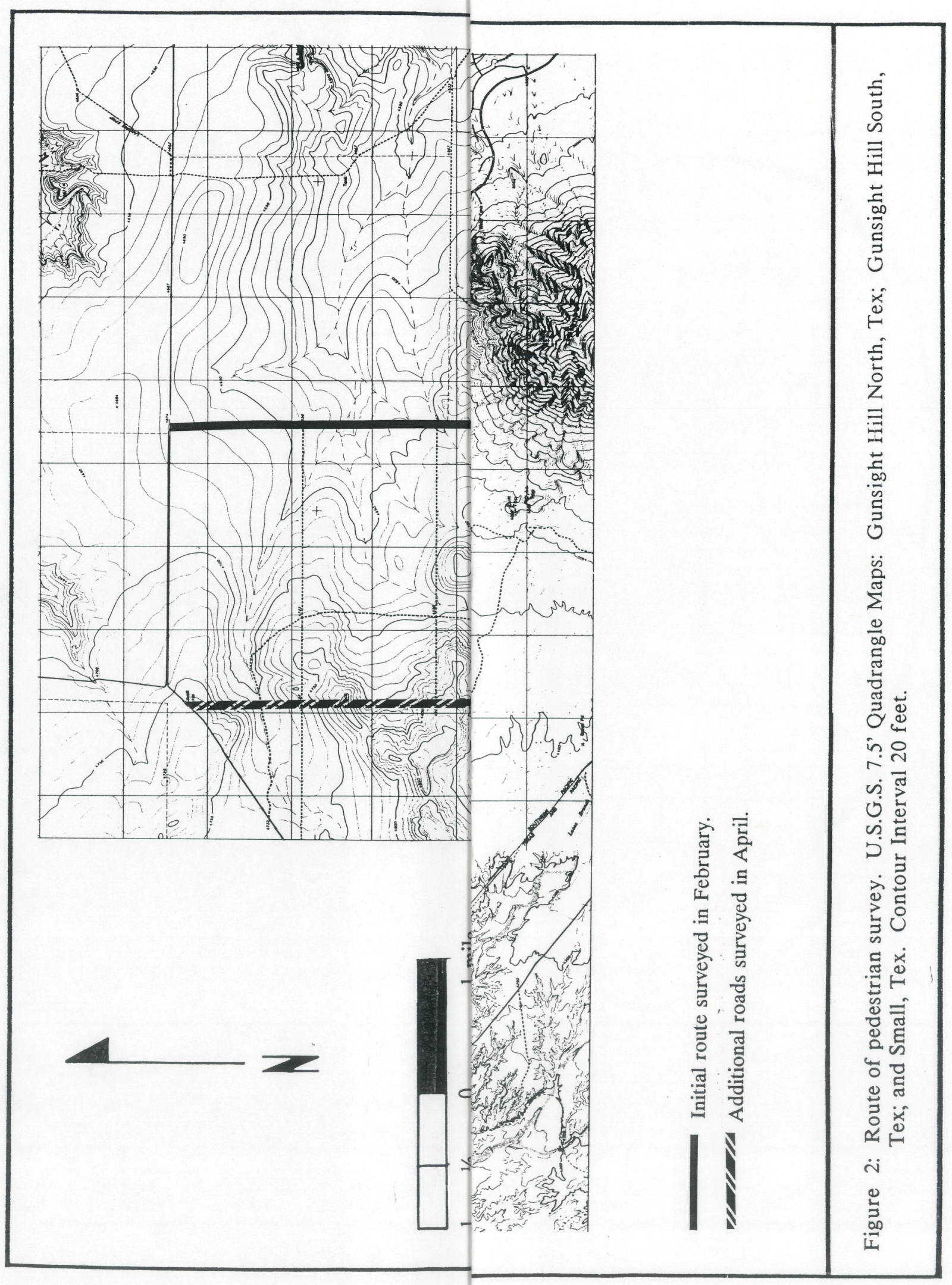




\title{
CHAPTER 2
}

\section{PROJECT SETTING}

\author{
Environmental Setting
}

\section{Geology and Geomorphology}

The Sierra Blanca project area is situated within the Trans-Pecos region. The Trans-Pecos consists of mountains and canyons and stretches of plateaus and plains between two relatively broad valleys: the Rio Grande on the west and the Pecos River on the east. Generally, the mountains are irregular in shape, trend south and southeast, and are separated by parallel belts of lowlands or bolsons. The Rio Grande is the only permanently flowing stream in the general project area. All other streams are ephemeral.

The geology in and around the Sierra Blanca project area is complex and features evidence of many geologic processes including faulting, folding, and igneous intrusions. Exposed rocks in and around the project area range in age from Precambrian to Recent, with nearly all geologic systems being represented. The majority of the rocks are of sedimentary origin; however, igneous rocks occupy a large part of Jeff Davis and Presidio Counties (Gates et al. 1980).

Unconsolidated Tertiary and Quaternary deposits fill the basins. Volcanic, volcanic-clastic, and intrusive rocks of Tertiary Age outcrop over much of the region including parts of the Quitman, Eagle, and Van Horn Mountains. These latter deposits also comprise most of the Sierra Vieja highlands south of the Wylie Mountains and the Davis, Chinati, and Bofecillos mountains (Gates et al. 1980). Limestone and sandstone rocks of Cretaceous age form outcrops on the southern Diablo Plateau between the Davis and Apache mountains and in the Van Horn Mountains. Rocks of Permian age, primarily limestone, outcrop in the Wylie, Apache, Delaware, and Guadalupe mountains and on the Diablo Plateau.

The Texas Lineament, a prominent structural feature crossing the project area along the northern side of Eagle Flat, is considered to be part of a transcontinental fracture zone by some geologists (Gates et al. 1980). At Eagle Flat, the Texas Lineament coincides with the boundary between the Diablo Plateau and the Chihuahua Trough. Structurally, this is a low area underlain by thick deposits of mostly Cretaceous age. Major geologic units and their water bearing characteristics are detailed in Table 1 .

Soils

The soil type within the project area is the Upton-Reakor soil association. These soils are found in the valleys, plains, and basins of the region. The soils occupy nearly level to strongly sloping areas on the uplands. This soil supports varying amounts of desert scrub vegetation in relation to annual rainfall amounts and a low level of openland, rangeland, and cropland when irrigated.

The soil association is composed primarily of Upton (50 percent) and Reakor ( 35 percent) soils. The remaining 15 percent is made up of the soils located along the drainways or shallow soils over limestone. The upper layer of the Upton soils is a light brownish gray, calcareous, gravelly loam about $12.7 \mathrm{~cm}(5$ in) thick with limestone and caliche pebbles $(<2.5 \mathrm{~cm}$ diameter) comprising 25 percent of the volume. The second layer is a pale brown, calcareous, gravelly loam about $20 \mathrm{~cm}$ (8 in) thick with limestone and caliche fragments comprising 25 percent of the volume. The third layer is a pinkish white indurated caliche layer. Reakor soils exhibit a surface layer of pink, calcareous loam about $20 \mathrm{~cm}(8 \mathrm{in})$ thick. The second layer is a light brown, calcareous, sandy clay loam about $40.6 \mathrm{~cm}$ (16 in) thick with a few 


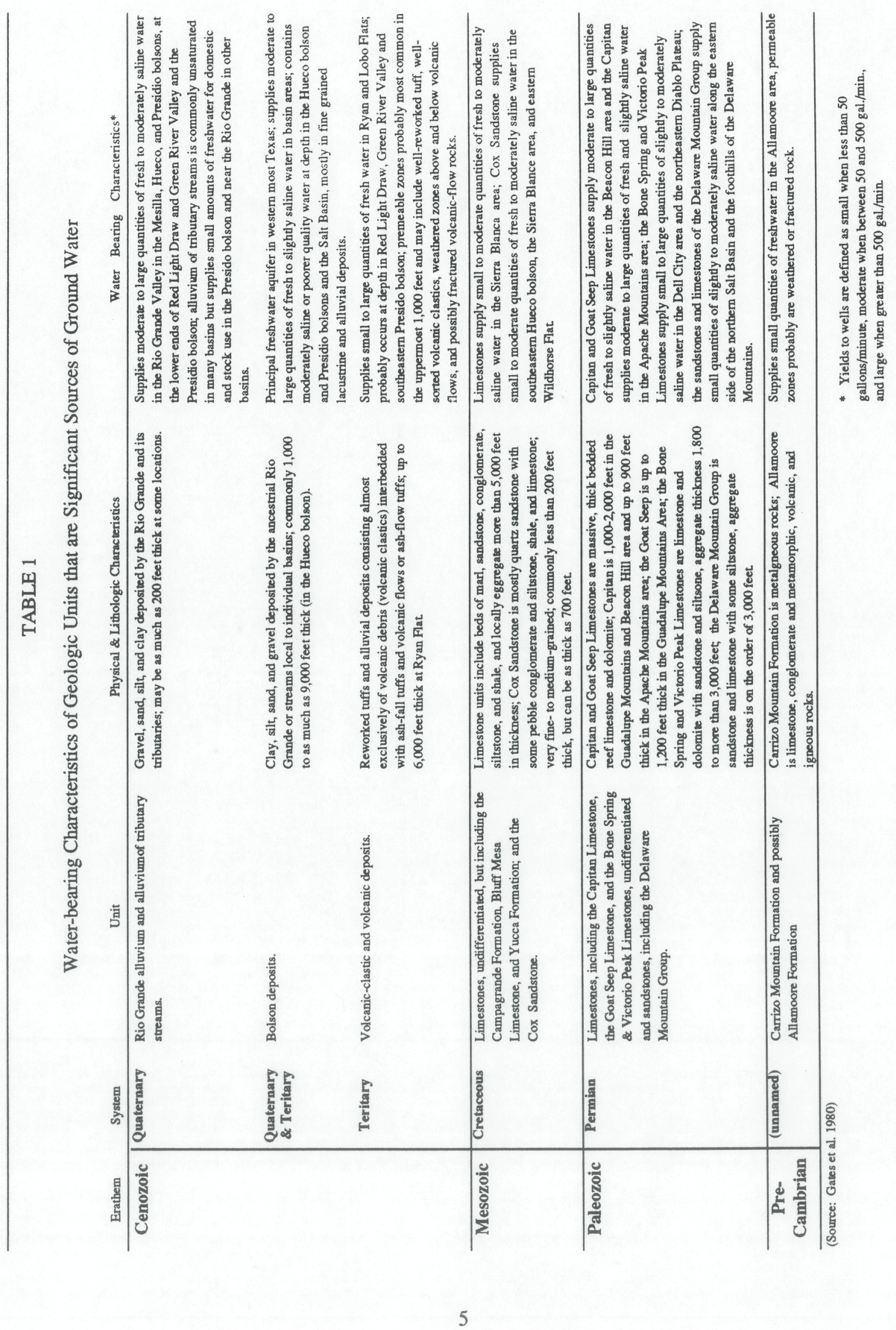


threads of calcium carbonate. The third layer is a pink, calcareous, clay loam about $30.5 \mathrm{~cm}$ (12 in) thick with visible concretions, soft masses, and threads of calcium carbonate. The fourth layer is a pink, calcareous clay loam.

\section{Climate}

Unless otherwise noted, the climatic conditions (long-term averages) described herein are a composite of data compiled by the U.S. Department of Commerce and National Oceanic and Atmospheric Administration (NOAA) at stations in Presidio, Van Horn (1941-1970), and Alpine, Texas (1951-1980). The climate in the area is arid sub-tropical with average total precipitation ranging from $21.9 \mathrm{~cm}(8.61$ in) to $37.7 \mathrm{~cm}$ (14.83 in) per year. Snowfall is rare and is considered of little importance. Irrigation is required to support plant life other than desert vegetation. Winters are characterized by fair, dry weather with mild days and cool nights. Freezes occur about half the time during December and January. The lowest recorded temperatures were

$-25^{\circ},-20^{\circ}$ and $-14^{\circ} \mathrm{C}$ at Van Horn, Alpine, and Presidio, respectively. Summer daytime temperatures range from warm (under $77^{\circ} \mathrm{C}$ ) at Van Horn to over $82^{\circ} \mathrm{C}$ at Presidio. The average wind speed is nine miles per hour ( $\mathrm{mph}$ ), usually from the north. Data from El Paso (1951-1960) indicate that the strongest winds have been recorded in the spring, averaging $11.3 \mathrm{mph}$ from the west-southwest.

The average annual precipitation for this area is between 23 and $25 \mathrm{~cm}(9-10 \mathrm{in})$, of which about 75 to 80 percent occurs from May through October. Showers greater than $0.3 \mathrm{~cm}(0.10 \mathrm{in})$ occur about once every 10 days during the summer. Very little precipitation occurs from February through April. Heavy snows (18-33 cm; 7-13 in) have occurred at Van Horn, but are so infrequent as to be considered insignificant. The area receives abundant sunshine all year long. Sunshine averages from 70 to 80 percent throughout the year. Cloud cover between sunrise and sunset at El Paso, Texas averaged 38 percent between 1951 and 1980. During an average year, 193 days would be clear; 99, partly cloudy; and 73 , cloudy.

\section{Flora}

The project area lies entirely within the Trans-Pecos mountain and basin ecological area of Texas (Gould 1969) and falls within the northern reaches of the Chihuahuan Desert (Hicks 1989:13). Of the seven major vegetative regions in the Trans-Pecos region (Schmidly 1977), two can be found in the Sierra Blanca project area and are illustrated in Figure 3. The majority of the project area is composed of grasslands and the minority is desert scrublands with some montane woodlands present in the higher elevations.

Dominant vegetation in the project area consists primarily of three types: 1) tobosa-black grama grassland (associated with grasslands), 2) creosote brush-lechuguilla shrub (associated with desert scrubland), and 3) grey oak-pinyon pine-alligator juniper parks/woods (associated with montane woodlands). Commonly associated plants with the tobosa-black grama grassland include blue grama, sideoats grama, Arizona cottontop, creosote brush, broom snakeweed, and white thorn acacia. Common associates of the creosote brush-lechuguilla shrub type include mesquite, yucca, catclaw acacia, prickly pear cactus, black grama, and tarbrush (McMahan et al. 1984). Commonly associated plants of the grey oak-pinyon pine-alligator juniper parks/woods include Gambel's oak, mountain mahogany, pine dropseed, blue grama, pinyon ricegrass, and heartleaf ground cherry.

Plants such as agave, sotol, yucca, Texas persimmon, prickly pear cactus, and ocotillo would have been economically important to the aboriginal inhabitants living in the Trans-Pecos area (Alexander 1970; Dering 1979; Mallouf 1985; Hicks 1989). Of these plants, agave, sotol, and yucca are found in the foothills (ca. 975-1675 m amsl), while Texas persimmon, prickly pear cactus, and ocotillo are found in the lower elevations (ca. 550-1065 m amsl). 


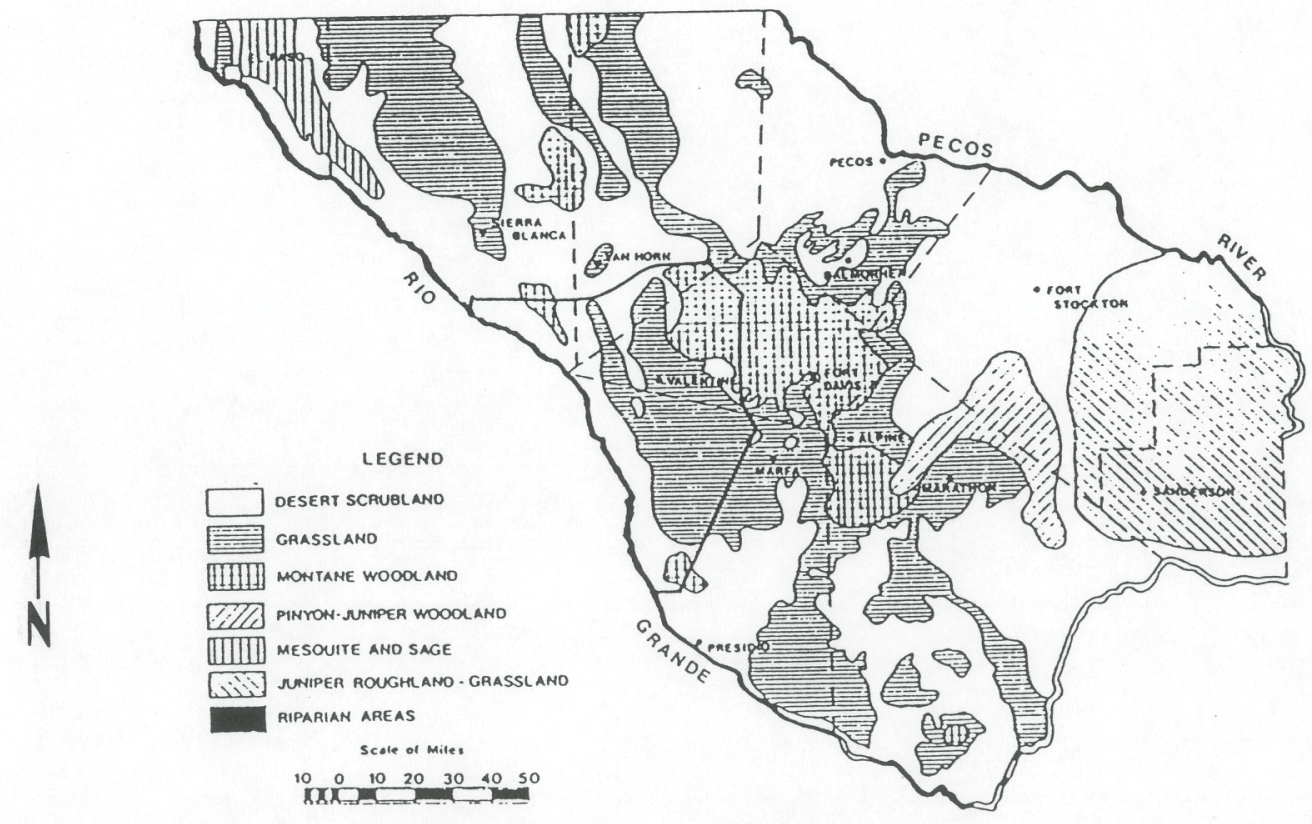

Source: Schmidly, D.J. 1977

Figure 3: Seven Major Vegetation Zones in the Trans-Pecos Region. 


\section{Fauna}

The Sierra Blanca project area has a diverse wildlife population including a wide variety of reptiles, amphibians, fishes, birds, and mammals (Hoffman et al. 1989:28-44). Generally, the wildlife range freely between the desert scrubland and grasslands vegetative regions while the animals within the montane woodland region tend to be more restricted in their movements (Schmidly 1977). Migratory birds may temporarily utilize the area's resources, with an average of seven genera being represented.

This abundant source of wildlife provided the prehistoric inhabitants with a wide range of animals for subsistence (Alexander 1970; Edwards 1990; Lord 1984; Sobolik 1988; Williams-Dean 1978). Among the mammalian population, eastern cottontail, black-tailed jack rabbit, rock squirrel, black-tailed prairie dog, hispid pocket mouse, plains harvest mouse, hispid cotton rat, white-throated wood rat, porcupine, raccoon, mule deer, white-tailed deer, pronghorn, and bison would have been important food resources found in the grasslands. Desert cottontail, black-tailed jack rabbit, Texas antelope, squirrel, Mexican ground squirrel, spotted ground squirrel, desert pocket gopher, silky pocket mouse, desert pocket mouse, banner-tailed kangaroo rat, coyote, ringtail, collared peccary, and mule deer would have been important food resources found in the desert scrubland. The montane woodlands would have been a source of eastern cottontail, rock squirrel, brush mouse, pinyon mouse, rock mouse, Mexican wood rat, Mexican vole, porcupine, black bear, white-tailed deer, and mountain (bighorn) sheep (Schmidly 1977). Additionally, ducks, turkeys, pigeons, bobwhites, and many species of turtles, lizards, and snakes most likely were exploited by aboriginal populations living within or traveling through the general project area. Accounts of other hunter-gatherer populations living within similar environments in south-central Texas indicate the use of similar resources (Ruecking 1953, 1955).

\section{Cultural Setting}

\section{Prehistoric Utilization}

The prehistory of the Trans-Pecos area can be broken down into five temporal periods (Hedrick 1988; Hicks 1989; Lehmer 1958; Mallouf 1985; Marmaduke 1978; Suhm et al. 1954;). Each temporal period is defined principally by the presence of diagnostic projectile points (Mallouf 1985), but is intended to represent more generalized developmental facies (based on subsistence practices, settlement pattern, technology, environment, etc.) within the Trans-Pecos area. It is important to note that the chronological framework for this region is cursory and that very little supporting data, outside of diagnostic artifacts, is available for any one period. Beyond stratified cave or rockshelter deposits, many of the diagnostic artifacts of a particular period often are found in mixed association with materials from other periods. Furthermore, the radiometric dating of any one period has been tenuous at best. Of the 51 published radiocarbon dates recovered from archeological sites in the Trans-Pecos area, only five are prior to 2000 B.P. and almost none were associated with diagnostic artifacts (Hoffman et al. 1989).

\section{Paleo-Indian Period}

The Paleo-Indian period (10,000 to 6500 B.C.) in the Trans-Pecos area is defined by the presence of basally ground, lanceolate projectile points which include Clovis, Folsom, Plainview, Golondrina, Meserve, Angostura, and Lerma types. Based on the temporal succession of these projectile points, the Paleo-Indian period can be divided on an interregional level into three subperiods commonly referred to as the Llano (early), Folsom (middle), and Plano (late). The Llano subperiod is recognized by the presence of Clovis points, the Folsom by Folsom points, and the Plano (in the Trans-Pecos area) by a series of unfluted points such as Plainview, Golondrina, Meserve, Angostura, and Lerma.

On a general level, the Paleo-Indian period represents the first well documented settlement of the New World by aboriginal peoples who crossed the Bering Land Bridge during the close of the Pleistocene 
epoch (ca. 11,500 B.P.). In the west, most Paleo-Indian sites have been found in the Great Plains east of the Rocky Mountains. Very few Paleo-Indian sites have been located in the Trans-Pecos area; however, the majority of the Paleo-Indian material which has been recovered in this region comes from the Rio Grande Valley (Hicks 1989). Sites along the Rio Grande tend to be situated on prominent terraces near sand dunes overlooking the valley (Anderson and Carter 1981; Quimby and Brooks 1967). In other parts of the Trans-Pecos region, Paleo-Indian occupations frequently have been found along playa shorelines (Betancourt 1981).

Social groups associated with the early Paleo-Indian period were probably highly mobile huntergatherers whose subsistence consisted of large Pleistocene herbivores, smaller animals, and plant resources. Group size would have been restricted primarily to small bands (less than 20 individuals) who traveled on a seasonal basis over great distances in pursuit of game or in acquisition of other kinds of food resources and raw materials. This kind of settlement pattern and subsistence strategy can be verified by the widespread interregional distribution of Clovis points often found hundreds of miles from the quarries from which they were produced. Much of what is known about the Clovis subperiod comes from kill sites where the bones of extinct Pleistocene megafauna (primarily mammoths) have been found in direct association with points and other lithic tools designed for butchering.

Due to the paucity of Paleo-Indian sites in the Trans-Pecos area, almost nothing is known about Clovis occupations in this region. In the interior subregion of the Trans-Pecos area, isolated finds (i.e., Clovis points) of early Paleo-Indian occupations are present; however, only two have been found so far (Hicks 1989; Lindsay 1969; Sommer 1974). The paucity of Clovis points may indicate that the interior subregion (as well as all of the Trans-Pecos area) was inhabited sparsely during the early part of the Paleo-Indian period and that groups merely passed through periodically from more heavily populated areas such as the Great Plains (Hicks 1989).

Data associated with the Folsom aspect of the Paleo-Indian period have been recovered more frequently from the interior subregion of the Trans-Pecos area. In the vicinity of Van Horn, there are a number of Folsom occupations (Hedrick 1975; Sommer 1974) and a significant habitation site has been recorded south of Van Horn along Wild Horse Draw (Betancourt 1981; Lehmer 1958; Lindsay 1969; Mallouf 1985:98). Unfortunately, there is not a published report on this site; nevertheless, several "dense concentrations of Folsom material," including hundreds of scrapers, knives, blades, channel flakes, gravers, and projectile points were found (Hicks 1989). It has been proposed that the Folsom period occupation in the Van Horn area was Plains-oriented (Mallouf 1981).

Several of lanceolate point finds associated with the Plano aspect of the Paleo-Indian period have been found in the interior subregion; however, these points usually have been found in mixed contexts with later occupations (Bradford 1980; Katz 1978; Mallouf 1985; Marmaduke 1978; Sommer 1974). In the vicinity of Van Horn, it appears that there was a continued presence of Paleo-Indian occupations from Folsom through Plano times (Hicks 1989).

Late Paleo-Indian finds (consisting of Plainview and other types of unfluted lanceolate points) in this area frequently are found along extinct playa shorelines and on creek terraces (Hicks 1989; Mallouf 1985). Based on the location of many of these occupations, it appears that late Paleo-Indian groups throughout the interior subregion were to some extent big game hunters pursuing bison and antelope in the lower elevations and deer and bighorn sheep in the higher mountainous region (Hicks 1989; Marmaduke 1978). It is suspected that during the late Paleo-Indian period and perhaps earlier, the Lobo Valley served as a major north-south corridor for migratory animals traveling between the Davis and Guadalupe Mountains (Hedrick 1988).

During this time (ca. 8000 B.C.), the climate in the interior subregion was becoming drier and many of the forested areas were being supplanted by plants and animals affiliated with the Chihuahuan Desert 
regime (Hedrick 1988; Mallouf 1981). Because of the encroachment of a desert climate, it is likely that big game hunting activities were curtailed significantly by the close of the Paleo-Indian period, if not earlier (Mallouf 1985).

\section{Early Archaic Period}

The Early Archaic period (6500 to 3000 B.C.) of the Trans-Pecos area is defined by the presence of projectile points which were stemmed and either corner- or side-notched. Examples are Martindale, Baker/Uvalde, Nolan, Pandale, and Bulverde points. Projectile points such as the Meserve (and possibly the Lerma), which frequently have been found in the Trans-Pecos area, clearly represent transitional forms between the Late Paleo-Indian and Early Archaic periods. Many of the Early Archaic cornerand side-notched forms also have ground bases.

As a cultural manifestation, the Early Archaic represents a period of adjustment from former PaleoIndian settlement/subsistence patterns of high mobility (partially or largely dependent on large migratory game) to a more localized hunting and gathering strategy based on a wider spectrum of plants and animals. Once in place, this kind of generalized Archaic pattern was to last for thousands of years in the Trans-Pecos area, changing very little over time (Shafer 1977; Taylor 1964). There can be little question that Early Archaic populations residing in the Trans-Pecos area also were adjusting to increasingly arid conditions which changed the landscape from a woodland/plains-like setting to more of a desert environment with much less biomass (Hicks 1989; Mallouf 1985). Under these changing climatic conditions, forests located within the river valleys probably migrated into the higher mountain zones (Mallouf 1985; Hicks 1989). However, it also appears that there were still savanna-grasslands containing a mixture of woodland and desert biota in some of the lower elevations (Mallouf 1985).

Outside the Big Bend area, there are very few known Early Archaic occupations in the interior subregion (Hicks 1989; Katz and Lukowski 1981; Mallouf 1985, 1986) and virtually none have been found in the vicinity of Sierra Blanca (Hedrick 1975). Early Archaic sites that have been located in the Big Bend area are situated in the higher elevations along arroyo terraces and ridgetops (Katz 1978). These sites consist of lithic scatters, burned rock middens, and hearth fields (Andretta 1976; Marmaduke and Whitsett 1975). A few rockshelters with Early Archaic materials also have been found (Andretta 1976; Marmaduke and Whitsett 1975). Based on the paucity of archeological data, it appears that the TransPecos area was sparsely populated during Early Archaic times; this may reflect the fact that the local environment was not conducive for long term settlement. However, the lack of Early Archaic sites in this area may be due to problems of recognition rather than a response to environmental conditions. Investigation of sites with dateable contexts is essential to the resolution of the problem.

\section{Middle Archaic Period}

The Middle Archaic period (3000 to 500 B.C.) in the Trans-Pecos area is defined by the presence of large stemmed, corner-notched, and side-notched projectile points, as well as some basal notched forms. Examples are Langtry, Val Verde, Castroville, Montell, Lange, Conejo, Almagre, Williams, Shumla, and Marcos points.

The Middle Archaic period in the Trans-Pecos area represents a continuation of the general Archaic lifestyle of broad based hunting and gathering. During this time, climatic conditions in the area became increasingly drier and warmer with some intervening wet spells (Mallouf 1981). Rockshelters in the eastern subregion and along the lower Pecos River to the east have yielded a wealth of information about the lifeways of Middle Archaic people, including a host of perishable remains such as basketry, matting, netting, cordage, sandals, and worked wood. In these areas, the Middle Archaic was flourishing with marked population increases relative to the earlier periods (Hicks 1989; Mallouf 1985). Indeed, 
and foreign wares including El Paso Brown, El Paso Polychrome, Chupadero Black on White, Jornada Brown, Three Rivers Red on Terra Cotta, Mimbres Black on White, Northern Mexican wares (polished tan, plain, corrugated tan, and Playas Red Incised), Galisteo Black on White, Black on Red Glaze, and Middle Pecos Micaceous Brown.

The earliest and most prolific Late Prehistoric occupations in the Trans-Pecos area occurred along the Rio Grande River near El Paso and can be identified culturally as the Jornada Mogollon (Kelley 1952a). Groups affiliated with this culture probably settled the El Paso area sometime after A.D. 200, lived in pit houses, and formed puebloan communities with above-ground structures by A.D. 1200 (Hicks 1989; Kelley 1952a; Lehmer 1958; Mallouf 1986; ). The Jornada Mogollon were agriculturalists and grew maize, squash, beans, and bottle gourds (Ford 1977; Whalen 1981). Farther to the south in the La Junta region near Presidio, similar puebloan communities were established along the Rio Grande and Rio Conchos by A.D. 1200 (Kelley 1952b; Kelley et al. 1940). It has been suspected by some that the La Junta settlements (identified as the Bravo Valley aspect) represent a southern movement of the Jornada Mogollon into the La Junta area (Lehmer 1958; Shackelford 1955). The populations of the La Junta pueblos were probably the immediate ancestors of the Patarabueye, with whom the Spanish made contact in the late sixteenth century (Kelley 1952a, 1952b, 1955, 1986; Lehmer 1958). Non-agricultural groups such as the historic Jumano (perhaps originating in the interior subregion) were probably in the La Junta region by Late Prehistoric times and lived periodically with the early Patarabueyes (Kelley 1952a, 1952b, 1955, 1986; Lehmer 1958; Mallouf 1985).

In the interior subregion, ceramics and the bow and arrow probably were introduced from the Rio Grande Valley as early as A.D. 300 in the north, and were present in other parts sometime after A.D. 900 (Hicks 1989; Mallouf 1985). To date, none of the Late Prehistoric occupations in the interior subregion appear to represent true agricultural settlements; cultigens have not been found in any convincing quantities. Nevertheless, sites with Jornada Mogollon ceramics have been found along alluvial fans, playa edges, and other level, low lying areas which would have been conducive to simple rain-based agriculture (Mallouf 1985). In the Davis Mountains, some maize cobs which appear to date to the Late Prehistoric period were found in a rockshelter. This may suggest that some interior groups were practicing horticulturalists (Mallouf 1985; Smith 1938).

Overall, it appears that Late Prehistoric populations in the interior subregion carried on subsistence strategies which were similar to those practiced in the Late Archaic (Hicks 1989). Indeed, sites remain virtually unchanged during the Late Prehistoric period except for the presence of ceramics and arrow points. On the other hand, ceremonial rock structures, stylized rock art, and purposeful inhumations are conspicuously present during this time (Hedrick 1988), suggesting that many groups living within the interior subregion were developing complex social and ritualistic systems not seen in the earlier periods. Furthermore, it is likely that hunter-gatherers from the interior were engaged in extensive contact with agriculturalists living along the Rio Grande Valley, as reflected by the relations between the Patarabueye and Jumano during early historic times (Mallouf 1985).

Late Prehistoric occupations are found throughout the area and there may have been a slight increase in the number of settlements after the end of the Late Archaic period. Due to the high frequencies of Livermore and Toyah arrow points found, Hedrick (1988) also believes that the greater Van Horn area may be the core area of Kelley's (1957) Livermore focus. Based on the ceramics found in the same area, it appears there were also contacts from the outside, involving the Jornada Mogollon of the Rio Grande Valley and possibly other groups from northern Mexico (Hedrick 1988). Since no heavy concentrations of ceramics were found anywhere in the greater Van Horn area, outside contacts made by the Jornada Mogollon or other agriculturalists probably were limited to sporadic trading forays (Hedrick 1988). Since there are salt flats associated with the Salt Basin just to the north of Van Horn and not more than $50 \mathrm{~km}$ from the Rio Grande Valley, it is conceivable that commodities such, as salt, would have attracted agricultural groups to the area on a periodic basis. 


\section{Historic Occupation}

The history of the interior subregion is based on the larger historic chronological framework of the Trans-Pecos area, which mirrors the general history of Texas and can be broken down into five basic temporal periods. Unlike the prehistoric periods, the historic periods are defined by key historical events and developments as interpreted from documentary information. Each historic period is intended to demarcate a particular socio-cultural facies (based primarily on the presence of certain European and North American settlements) within the Trans-Pecos area.

\section{Spanish Exploration Period}

The Spanish Exploration period (A.D. 1535 to 1659) is represented by the presence of European explorers in the Trans-Pecos area. The period began around 1535 when Cabeza de Vaca and others of the ill-fated Narváez expedition passed through the area on their way to Culiacan, Mexico, on the Pacific coast. No traces of Cabeza de Vaca's travels have been found in the Trans-Pecos area; however, it is likely that he and others of the expedition passed through parts of the interior subregion south of Van Horn (Fox 1983; Pool et al. 1975). Existing Native Americans noted by Cabeza de Vaca in the interior subregion were nomadic hunter-gatherers possibly affiliated with the Jumano (Kelley 1952b; Mallouf 1985; Riley 1987). Other expeditions, by Rodriques-Chamuscado (1581), by Espejo (1582), and by Oñate (1598), followed Cabeza de Vaca and passed through the Trans-Pecos area. These particular expeditions started from the small colonial town of Santa Barbara in northern Mexico and followed the Rio Conchos north to the confluence of the Rio Grande and Rio Conchos called La Junta de los Rios (Pool et al. 1975). At La Junta, these early Spanish explorers noted both Patarabueyes and the Jumano living, trading, and interacting with each other along the Rio Conchos and the Rio Grande (Kelley 1952b). Unlike Cabeza de Vaca, these later explorers did not venture deep into the interior subregion, but traveled mainly along the river routes skirting the Trans-Pecos area. However, Espejo did cross overland from the upper Pecos River to the la Junta area, somewhere to the east of Van Horn on his way back to Mexico (Fox 1983; Kelley 1952b). Oñate, noted for his founding of Santa Fe, traveled up river on the Rio Grande from La Junta through the El Paso area up into New Mexico. Other than establishing base camps along the Rio Grande in the La Junta and El Paso areas, no permanent settlements were established by the Spanish in the Trans-Pecos area during this time.

Very little to no archeological information has been recovered from these first Spanish occupations in the Trans-Pecos area, and any traces conceivably dating to the Exploration period more than likely would be found along the Rio Grande River near La Junta or El Paso. In the interior subregion, there are no known sites dating to this period.

Spanish Colonial Period

The Spanish Colonial period (A.D. 1659 to 1821) in the Trans-Pecos area began with the establishment of a mission and frontier outpost near El Paso in 1659 (Hicks 1989; Jenkins and Schroeder 1974). As a result of the Pueblo Revolt in 1680, refugee Spanish colonists from Santa Fe and other northern Rio Grande settlements relocated to the small mission complex at El Paso (called Our Lady of Guadalupe) and established a permanent community there (Jenkins and Schroeder 1974). Shortly thereafter in 1683, several missions and presidios were set up farther down river in the La Junta area (Kelley 1952b). These later missions were established at the request of the aboriginal populations residing in the La Junta area, mainly for protection against incoming hostile Plains Indians, and also for reasons of consolidating the frontier boundaries along the northern borderlands claimed by the Royal Government. The La Junta mission settlements were occupied and abandoned intermittently until 1732 when they were occupied permanently until the end of the Spanish Colonial period (Kelley 1952b; Tyler 1975). 
During this time, Apaches and Comanches also entered the Trans-Pecos area from the territory of New Mexico and carried on adversarial relationships with the Spanish colonists and Native American mission neophytes. These activities consisted of raids and counterattacks which took place chiefly along the Rio Grande Valley. As a result of the Apache and Comanche raiding, more missions and presidios were established throughout the Rio Grande Valley in the Trans-Pecos area (Tyler 1975). By the last quarter of the eighteenth century, many Native Americans from the plains were using the Trans-Pecos area extensively as a place of refuge and raiding. As a result, military expeditions such as those carried out by Ugalde in 1787 to repel the marauding tribes, were commissioned regularly by the Spanish authorities (Hicks 1989). Military campaigns were carried out until 1791 when a peace treaty was agreed upon by all of the warring parties (Tyler 1975). Nevertheless, the Comanche (as well as some Apaches) continued their raiding activities in the Trans-Pecos area through the first half of the nineteenth century (Hicks 1989).

At the turn of the eighteenth century, the Spanish colonial mission-presidio system declined considerably in Texas and other parts of the northern Spanish borderlands as a result of the disintegrating Spanish Colonial Empire (Poyo and Hinojosa 1991). By the 1790s the Rio Grande missions of the Trans-Pecos area, as well as all other missions in the borderlands, were secularized and decoupled from centralized Spanish authority (Poyo and Hinojosa 1991). By the early 1800s, Spanish colonials and neophyte Native Americans along the Rio Grande Valley abandoned the mission system and merged into more integrated Hispanic communities centering around the old mission-presidio complexes. The inhabitants of these Rio Grande communities were engaged primarily in subsistence farming and small-scale ranching.

Other than the Mendoza-Lopez expedition which left La Junta in 1683 and crossed the interior subregion on its way to explore central Texas, there were virtually no Spanish colonial occupations or encampments outside the Rio Grande Valley in the Trans-Pecos area. Like the Spanish Exploration period, there are no known archeological sites in the interior subregion which date to this period. However, it is conceivable that Apache or Comanche camps dating to this period may exist in some parts of the interior subregion, perhaps in the Van Horn area.

\section{Mexican Colonial Period}

The Mexican period (A.D. 1821 to 1836) begins with the political independence of Mexico from Spain in 1821. This period is characterized by the Empresario Grant system, initiated in the closing days of the Royal Spanish Government and carried on by the newly independent Mexicans, which allowed settlement of the Texas borderlands by Anglo-Americans and immigrant Europeans. In the Trans-Pecos area, no Empresario land grants were issued, and as a result, no new settlements were added along the Rio Grande Valley or in other parts of the interior. For the most part, the lives of the local inhabitants along the Rio Grande remained essentially the same as they had been during colonial times. Nevertheless, Hispanic communities in this area continued to become more independent from the policies of Mexico City.

\section{Texas Republic and Nineteenth Century American Period}

This period (A.D. 1836 to 1900) began with the establishment of the Republic of Texas in 1836 and the subsequent annexation of Texas into the United States in 1845. During the first half of the nineteenth century, the role of Texas in the trade between the United States and Mexico increased significantly. As a result, local centers such as San Antonio and El Paso grew proportionately and there was a need to improve previous overland trade routes such as the Santa Fe Trail and the Camino Real, as well as to create new trails which could cross-connect with the older routes. By the end of the 1840s the Chihuahua Trail connected Chihuahua City, Mexico, to Indianola, Texas, on the Gulf Coast (Tyler 1975). This trail followed the old Spanish route along the Rio Conchos to La Junta and then crossed overland 
to the northeast. The importance of the Chihuahua Trail in the Trans-Pecos area was twofold in that it (1) diverted some of the trade from the Santa Fe Trail, promoting more interaction with urban areas such as San Antonio, and (2) helped to establish new settlements (posts, forts, and towns) in the interior subregion (Hicks 1989). Other smaller east-west trails (Neighbors-Ford and Smith and Whiting) were also blazed through the Trans-Pecos area from El Paso to San Antonio by 1849 (Pool et al. 1975). Both these trails passed near the vicinity of Van Horn and the Neighbors-Ford Trail passed through the Van Horn Mountains.

With the annexation of Mexican lands by the United States after the Mexican-American War (18461848), settlement of the Trans-Pecos area by Anglo-Americans increased significantly. Fort Leaton and the town of Presidio were established in the La Junta area by 1848 and systematic mapping projects of the Trans-Pecos region were initiated in the early 1850s (Tyler 1975). From the Corps of Topographic Engineers, the naturalist-scientist William Emory made systematic observations of the environment along the Rio Grande Valley and adjacent mountain areas and passed through the Van Horn area in 1852 (Pool et al. 1975). Fort Davis was established in 1854 to protect a newly blazed road from hostile Native Americans, primarily Apache and Comanche. The road was originally surveyed in 1850 (Tyler 1975). Shortly thereafter, the U.S. Army also set up a small garrison from Fort Davis at Van Horn Wells in the northwest (Wylie 1973). Van Horn Wells was established near a natural spring which was situated just south of the modern town of Van Horn at the northeastern edge of the Van Horn Mountains. Based on an oral history from local 85-year-old Van Horn resident Evans Heans, there was a small military outpost located four to five miles "up stream in Van Horn Canyon on Soldier Springs Ranch - Diez y Ocho Camp". Apparently this outpost was occupied until World War I. Another outpost called the "Valentine Fort" also was established somewhere in the vicinity of Van Horn (Bearden 1977). Many of these smaller establishments were set up by private landowners for protection against Indian attacks (Wylie 1973).

With the influx of prospectors and entrepreneurs passing through the Trans-Pecos region on their way to the California gold fields (Wylie 1973), more attention was focused on the interior subregion as a potential area for mining. As a result, silver mining began in the Chinati Mountains by 1860 and other mines were established a few years later in the vicinity of Marfa (Tyler 1975).

Many of the newly established nineteenth century forts and settlements in the Trans-Pecos area suffered as a result of the relocation of troops to the southeast during the Civil War. Fort Davis was abandoned, and as a consequence, raiding activities by the Apache and Comanche increased significantly. Depredations by the Native Americans were serious enough to force many settlers out of the area. Fort Davis was reestablished several years after the end of the war and Native American hostilities subsided until 1876, when they resumed (Hicks 1989). Many of these later raids were initiated by the Mescalero Apache under the leadership of Victorio. These raids lasted until his death in 1880 (Hicks 1989; Tyler 1975;). It is worth noting that somewhere in the Eagle Mountains or an adjacent area there is an alleged battle ground (date unknown) where a contingent of African-American soldiers fought some Indians. Apparently some of the soldiers were killed and buried on the site (Wylie 1973).

Based on the oral history of Evans Heans, who moved to Van Horn in 1903, Indians camped "up and down" an unnamed river, perhaps Wild Horse Draw, where they "used to build a big fire, then take the rocks out and lay their venison or whatever on those hot rocks to cook it" (Bearden 1977). Heans was asked if this was the same way that the Native Americans (not named) cooked plants. He said "No, to cook Sotol they dug a well like arrangement and put a fire in the well, the[n] put the plants in and cover[ed] them over until cooked" (Bearden 1977). According to Heans, the traces of these Native American encampments at one time could have been found along the edges of the river, but are scarce today because the sites have "been picked over" (Bearden 1977). 
Significant increases in settlement of the Trans-Pecos area, especially in the interior subregion, began to reoccur after the end of Indian hostilities and the arrival of the railroads in the early 1880s (Hicks 1989). The Southern Pacific Railroad linked El Paso with Sierra Blanca, which in turn fed out to the interior settlements of Pecos and Marfa (Pool et al. 1975). Van Horn was established as a railroad water depot in 1881 (Hoffman et al. 1989). Nine years earlier Presidio County was established and Jeff Davis County was later founded in 1887. As a result of the railroads, cattle ranching became a leading industry in the interior subregion (Hicks 1989). Between 1880 and 1890, approximately 90 percent of the cattle ranches in Presidio County were established (Hoffman et al. 1989). With the discovery of mercury in 1894, mining also increased significantly around the Big Bend area and other parts of the interior subregion (Tyler 1975). During this period, copper, lead, iron, silver, tin, manganese, sulphur, fluorite, marble, and salt were mined in large quantities around the Van Horn area (Hoffman et al. 1989).

The implementation of irrigation systems coupled with the cultivation of cotton (ca. 1870s), the use of barbed wire (ca. 1880s), and the introduction and subsequent breeding of Hereford cattle (ca. 1885) were other late nineteenth century innovations which increased settlement in the interior subregion and were to have a lasting effect on the economy (Hoffman et al. 1989).

\section{Twentieth Century American Period}

The twentieth century American period represents the modern era. In the Trans-Pecos area, cattle ranching and mining continued to prosper and settlements in the interior subregion increased in size and number. In the Big Bend area, candelilla wax factories were established in 1911 and "continue[d] to be a major industry on both sides of the border" (Hicks 1989). Culberson County was established in 1912 and Van Horn became the county seat. Hudspeth County was established five years later in 1917 with Sierra Blanca as the county seat. During the 1900s, the town of Van Horn became a local center of commerce, agriculture, and mining (Wylie 1973).

Nevertheless, the interior subregion as a whole remained sparsely populated with a scattering of small communities and isolated ranches (Hicks 1989). Due to the basin and range topography and low population density, this area sustained its old reputation as a place of refuge and was used extensively between 1912 and 1920 by Pancho Villa and other Mexican revolutionaries as a staging ground for raids along the border (Hicks 1989). Based on the oral history of Evans Heans, there was a raid (called the Heville Raid) by Mexican revolutionaries somewhere in the Van Horn area (Bearden 1977). As a consequence, the U.S. Government sent troops into the general area and more than 100,000 National Guardsmen were stationed along the border zone in 1916. According to Heans, a town called Pilares (located on the border south of Van Horn ?) was burned "on both sides of the river" by soldiers (U.S.?) and a "lot of people were killed" there. The burning of Pilares occurred sometime after 1918 (Bearden 1977).

By the early 1920s, conditions along the border became more stabilized (Tyler 1975) and the interior subregion of the Trans-Pecos area took on its modern character of small western mining and ranching towns with large cattle ranches filling in the otherwise vacant basin and range country. Today, much of the interior subregion gets its revenue from tourism. The various small towns provide a stopping point for tourists traveling through the area (Wylie 1973).

\section{Previous Archeological Investigations}

The culture history of the Sierra Blanca project area falls within the interior subregion of the TransPecos area and recently has been summarized by Hedrick (1988), Hicks (1989), and Mallouf (1985). Other than the works of Kelley (1952a, 1952b, 1955, 1986), most of the archeology in the Trans-Pecos area has focused on the prehistoric past. The first archeological publications dealing with the prehistory 
of the Trans-Pecos area focused on the excavations of caves and rockshelters which produced numerous finds of perishable items not commonly found in other parts of Texas (Coffin 1932; Holden 1938, 1941; Howard 1932; Mera 1938; Sayles 1935; Smith 1932, 1933, 1934, 1938; Smith and Kelley 1933). Spectacular rock pictographs and petroglyphs, predominantly found in the eastern parts of the TransPecos region and along the lower Pecos River, were reported by Jackson (1938) and Kirkland (1937). Most of the significant sites in the Trans-Pecos area were excavated prior to 1940, and since then, archeological investigations have been limited to smaller scale operations dealing mostly with the subsurface testing of sites (Hoffman et al. 1989). In the last 20 years, over 90 percent of the archeological work done in the region has been associated with cultural resource management programs (most of which have been reconnaissance in nature) involving pedestrian surveys and site testing (Hoffman et al. 1989).

Although systematic acheological research has been conducted in the interior since the late 1950s (Banks 1975; Betancourt 1981; Cliff and Fifield 1980; Foster and Kelley 1987; Gerald 1978; Hedrick 1968; 1975; 1986; Lehmer 1958; Lindsay 1969; Skinner and Bousman 1973), the Sierra Blanca project area has not been the focus of attention. A previous archeological survey was carried out in 1973 near Sierra Blanca by Southern Methodist University's (SMU) Archaeological Research Program (ARP) for the Diamondhead Corporation. This survey was conducted to determine the cultural resources present within the property owned by the Diamondhead Corporation, located north and east of Sierra Blanca. The property, Milehigh, was scheduled for development; therefore, more than 1,000 acres were projected to be impacted by the construction. The survey located and recorded two historic sites, 53 prehistoric sites, and 62 sites with undetermined usage for a total of 117 archeological sites. The pedestrian survey recorded rockshelters, hearth fields, ring middens, mortar holes, pictographs, petroglyphs, and scatters of lithic debris and ceramics. The 1973 survey area borders and is southeast of the present project area. Lithic debris representing 58 percent of the cumulative artifact assemblage, was the largest artifact class. Ceramics comprised the remaining 42 percent of the artifact assemblage. Ceramics were located on all sites sampled with the exception of 15 sites. A total of 16 different ceramic types was recovered during the 1973 survey at Milehigh. The artifacts recovered at Milehigh established prehistoric occupation in the area between A.D. 900 and 1400 (Skinner et al. 1973). 


\section{CHAPTER 3}

\section{METHODOLOGY}

The initial investigation of the project area began with a background check at the Texas Archeological Research Laboratory (T.A.R.L.) for site forms from previously recorded sites within the project boundaries. No sites are presently listed with T.A.R.L. for the survey area. Site 41HZ394 is located in the general project area and is a historic, open campsite (ca. 1900 to 1935) believed to have been used for short term occupation. However, the site is outside and west of the project area. The Milehigh survey conducted by Southern Methodist University recorded two sites within the project area. Site $\mathrm{x} 41 \mathrm{HZ} 21$ is a $600 \mathrm{~m}^{2}$ prehistoric site with circular limestone hearths and scattered Jornada Brownware pottery. No information is provided on the second site which is unnumbered (Skinner et al. 1973).

The present pedestrian survey investigated $42.7 \mathrm{~km}$ (26.5) miles of unpaved roads proposed for improvements with the work being conducted February 25 to 28, 1992. An additional $7.6 \mathrm{~km}$ (4.75 miles) were surveyed during the monitoring phase (March 31 to April 22) for a total of $50.3 \mathrm{~km}(31.25$ miles). The proposed route was surveyed 50 meters to either side of the road. Each side of the road was covered by two crew members walking parallel transects: the first 25 meters from the road and the second an additional 25 meters from the first transect. Since an existing road was surveyed, not all areas could be surveyed 50 meters to either side. Some segments of the survey road are bordered by fencelines. However, these fences will not be destroyed or moved for the road construction to be carried out (Saathoff, personal communication). Therefore, in those areas where fences limited survey on either side of the road, the area was surveyed by transects spaced at 30 meter intervals, with crew members walking in a zig-zag pattern, to cover an area of 100 meters from the road. This distance follows the specification outlined in the Scope of Work and attempts to account for any unforseen changes which may occur if the road needs to be rerouted once construction begins.

Recognition and definition of sites was accomplished through the examination of surface material only. Additionally, no artifactual materials were collected. In order to be recognized as a site, a cultural manifestation had to meet one of the following criteria: (1) a surficial scatter with no associated subsurface deposits and a minimum of three artifact classes; (2) presence of burned rock middens or rings; (3) presence of cultural features, such as hearths, with associated cultural material; and (4) separation from adjacent cultural manifestations by a distance of 100 meters. Isolated finds were recorded as "localities" and were defined by one piece or a small concentration of pottery, lithics, fire cracked rock (FCR), etc. not associated with a larger scatter or diagnostic material(s). Each isolated

find was numbered, a description of the materials recorded, and its location plotted on a U.S.G.S topographic map.

Material concentrations that were designated as a site area were recorded on a State of Texas site form, a pace and compass map was drawn, photographs (black and white photographs and color transparencies) were taken, and the area was plotted on a U.S.G.S. topographic map. A single shovel test was excavated within a site area to better understand the geological context of the site. The sediment from the shovel test was screened through $6.35 \mathrm{~mm}\left(1 / 4^{\prime \prime}\right)$ wire mesh to document the presence or absence of subsurface artifacts. No subsurface materials were observed. 


\title{
CHAPTER 4
}

\section{RESULTS AND RECOMMENDATIONS}

\author{
Survey Results
}

A total of $50.3 \mathrm{~km}$ (31.25 miles) was surveyed for cultural resources near Sierra Blanca (see Figure 2). Some of the increased distance (initially $42.7 \mathrm{~km}$ were proposed) provided coverage of segments of the road that required only grader leveling and not full scale repair. Also, the additional kilometers included sections of the road that needed to be rerouted to increase the longevity of the road repair and to provide an alternative route around a house being constructed by a landowner in the middle of the existing road.

Two known sites ( $\mathrm{x} 41 \mathrm{HZ} 21$ and a second unnumbered site located $0.45 \mathrm{~km}$ south of $\mathrm{x} 41 \mathrm{HZ} 21$ ) have been previously recorded along the proposed road as part of the Milehigh survey (Skinner et al. 1973). Site $\mathrm{x} 41 \mathrm{HZ} 21$ was described as being $40 \mathrm{~m} \mathrm{~N} / \mathrm{S} \times 15 \mathrm{~m} \mathrm{E} / \mathrm{W}$ at an elevation of $1,363 \mathrm{~m}(4,470 \mathrm{ft})$ amsl. The previous survey located a dozen eroded limestone hearths, burned stone, and five pieces of Jornado Brownware within the site area. However, no lithic debris or stone tools were present. Site $\mathrm{x} 41 \mathrm{HZ} 21$ is plotted at the location of the recently designated Locality 8. Locality 8 , however, consists of one cortical flake; no other artifacts or features were observed within the area. The present survey did not relocate a site or a locality at the location of the second unnumbered site. Almost 20 years of erosional impacts likely precluded the relocation of these sites.

A section of the initially proposed route for road improvements had to be rerouted to place the road on a rock surface and not on the sandy valley floor (see Figure 2). This was done to help increase the longevity of the road repairs and to keep the road from being eroded and gullied by water runoff. Additionally, small " $\mathrm{v}$ " ditches were cut at various intervals along the road to channel water away from the road, thus preventing the rutting of the road by water runoff. Bullheads were placed across the road at the location of the " $\mathrm{v}$ " ditches. These rounded, dirt mounds aid in funneling water into the " $\mathrm{v}$ " ditches to prevent erosion of the road.

A total of two sites and 17 isolated finds was located and recorded during the pedestrian survey of the proposed road improvements (Figure 4). All of the right-of-way surveyed has been impacted significantly by erosion as a result of overgrazing. Both site areas fall within the Upton-Reakor soil association. Cultural material was observed on the uplands and in the basin between the hills. However, no artifact type was found consistently on a specific landform. Prehistoric material observed consisted of various types of pottery, lithic debitage, and three manos. No significant historic materials were observed.

\section{Site $41 H Z 499$}

Site $41 \mathrm{HZ} 499$ is $0.7 \mathrm{~km}$ southwest of the "Y" junction in the survey road shown on the Gunsight Hills South, Tex 7.5' U.S.G.S. quadrangle map (1979) at an elevation of 1,359.75 m (4,460 ft) amsl. Also, the site area is $2.176 \mathrm{~km}$ northeast of Pajaro Tank. The site area measures $5,525 \mathrm{~m}^{2}(85 \mathrm{~m} \mathrm{E} / \mathrm{W} \mathrm{x} 65 \mathrm{~m}$ $\mathrm{N} / \mathrm{S}$ ) (Figure 5). The site is located on the basin floor with hills to all sides. An intermediate drainage is located $150 \mathrm{~m}$ south of the site area. The vegetation on the site consists of various grasses, Spanish Dagger, and creosote bushes.

The ceramic artifacts observed on the site include five redware sherds, eight plainware sherds, two sherds with a brown exterior and a burned red interior, and two sherds of El Paso Brownware. Lithic 


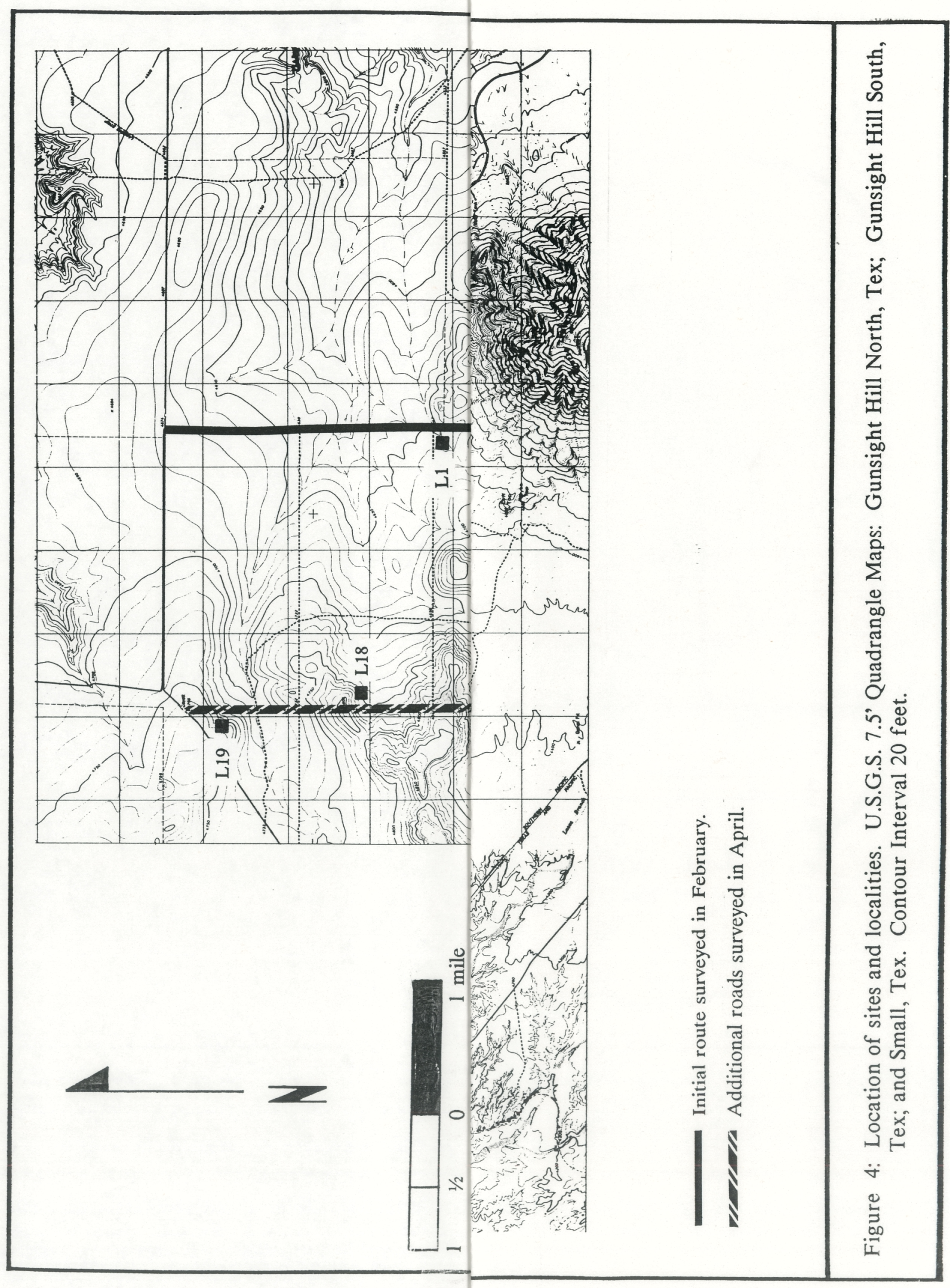




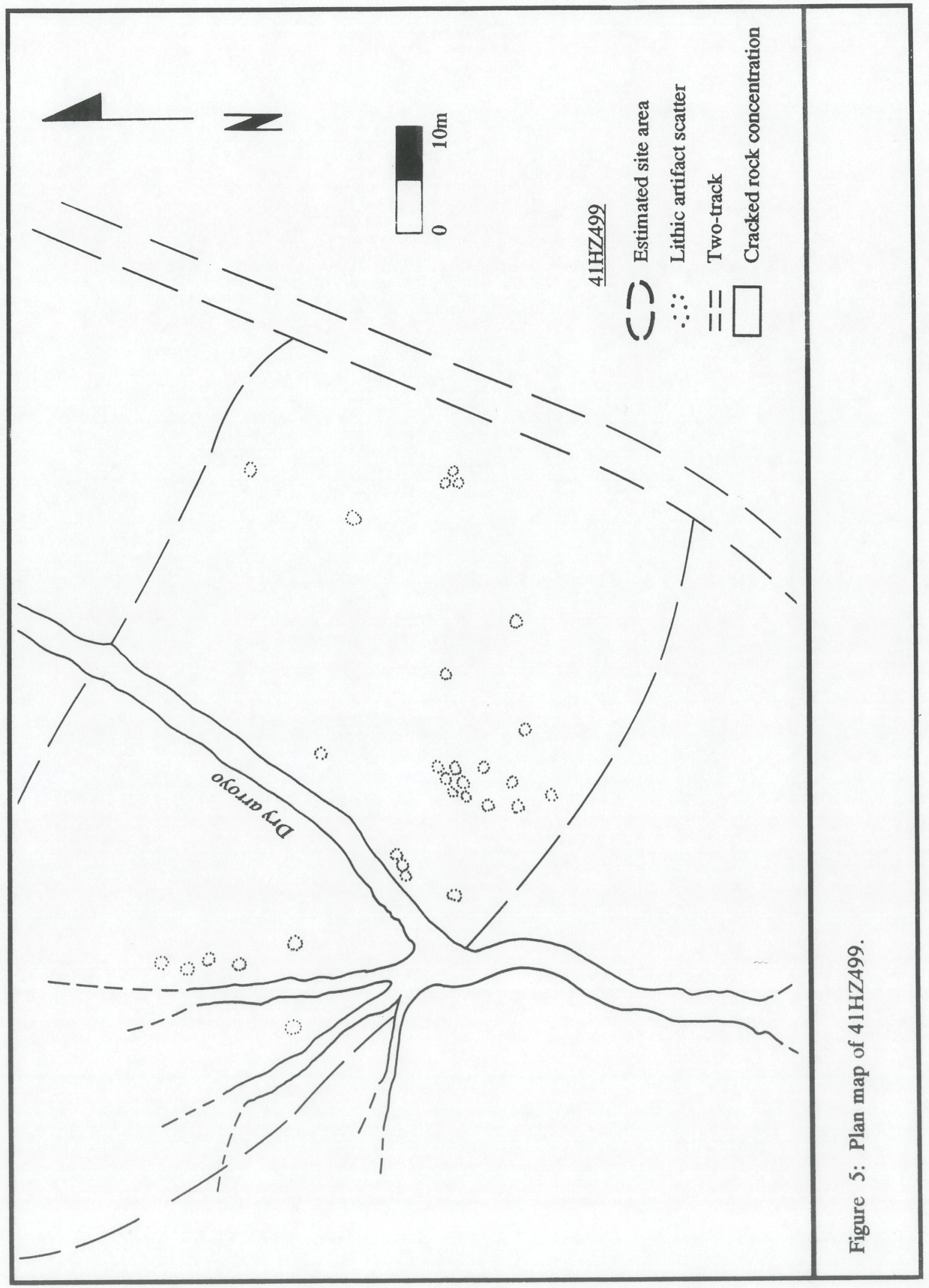


materials consist of two flakes of black quartzite; two flakes of green quartzite; two flakes of a light green shale-type material; one flake of white chalcedony; a scraper of mottled quartzite; two flakes of purple quartzite; and one flake of a white/cream chert. Two modern items were found within the area: a 3006 bullet and two tin cans. No features or diagnostic projectile points were observed within the site area.

The site appears to have been an open campsite. The absence of features and lack of a nearby, permanent water source suggest that the location was only a temporary activity area. A mixture of ceramics and lithic materials are scattered across the surface. Although the extremely low artifact density suggests that the site has limited research potential, the lack of adequate subsurface testing precludes an evaluation of the potential for subsurface deposits. Therefore it was recommended that site $41 \mathrm{HZ} 499$ be considered to be of an "unknown" eligibility status and that the site area be avoided by the road improvements. During the construction phase in April of 1992, the archeological monitors worked with the JTF- 6 personnel to ensure that site 41HZ499 was avoided.

\section{Site $41 H Z 500$}

Site $41 \mathrm{HZ} 500$ is located near the bottom of a slope (3-4\%) that is $0.7 \mathrm{~km}$ south of Cement Tank at an elevation of $1,463.4 \mathrm{~m}(4,800 \mathrm{ft})$ amsl. The tank is shown on the Gunsight Hills South, Tex. 7.5' U.S.G.S. quadrangle map. The site area is $14,400 \mathrm{~m}^{2}(160 \mathrm{~m} \mathrm{E} / \mathrm{W}$ x $90 \mathrm{~m} \mathrm{~N} / \mathrm{S})$ (Figure 6). The site is located on an upland landform that slopes west-southwest to an intermediate drainage at the bottom of a canyon. The vegetation on the site consists of various grasses and creosote bushes.

The lithic materials observed within the site area include 59 flakes of yellow jasper; one flake of a finegrained, red chert with white veins; three flakes of a black, fine-grained material; two flakes of a finegrained, grey material; two brown quartzite flakes; one green quartzite flake; one core of a light green shale-like material; one brown quartzite biface; and one yellow jasper biface. The brown quartzite biface measured $4 \mathrm{~cm} \times 6 \mathrm{~cm}$ with a thickness of about $2 \mathrm{~cm}$. The yellow jasper biface measured $5 \mathrm{~cm}$ $\mathrm{x} 6 \mathrm{~cm}$ with a thickness of about $1.5 \mathrm{~cm}$. The crude flaking of both specimens indicates that they were discarded during an early stage of reduction. The ceramic assemblage observed on the site consists of one very small redware sherd. No features or diagnostic projectile points were observed within the site area.

Site 41HZ500 appears to have been an open campsite/reduction site based on the low density of material and types of lithic materials recovered. The limited subsurface testing makes it difficult to determine the research potential of the site. Therefore, it is recommended that the site area be avoided during road improvement work until a final determination of National Register eligibility is made. The site area was monitored during construction to ensure that the site context was not impacted.

\section{Localities}

The isolated finds observed on the pedestrian survey were plotted on U.S.G.S. topographic maps and a description of the artifact recorded. The areas around the localities were intensively checked for additional artifacts and/or features that would indicate the presence of a larger activity area; however, none were observed. The localities are not eligible for NRHP consideration because of their lack of research potential (see Figure 4).

$$
\begin{aligned}
& \text { Locality } 1: \quad \text { a basal portion of a chalcedony dart point } \\
& \text { Locality } 2: \quad \text { a tertiary flake of white quartzite } \\
& \text { Locality } 3: \quad \text { a dark gray, tertiary flake }
\end{aligned}
$$




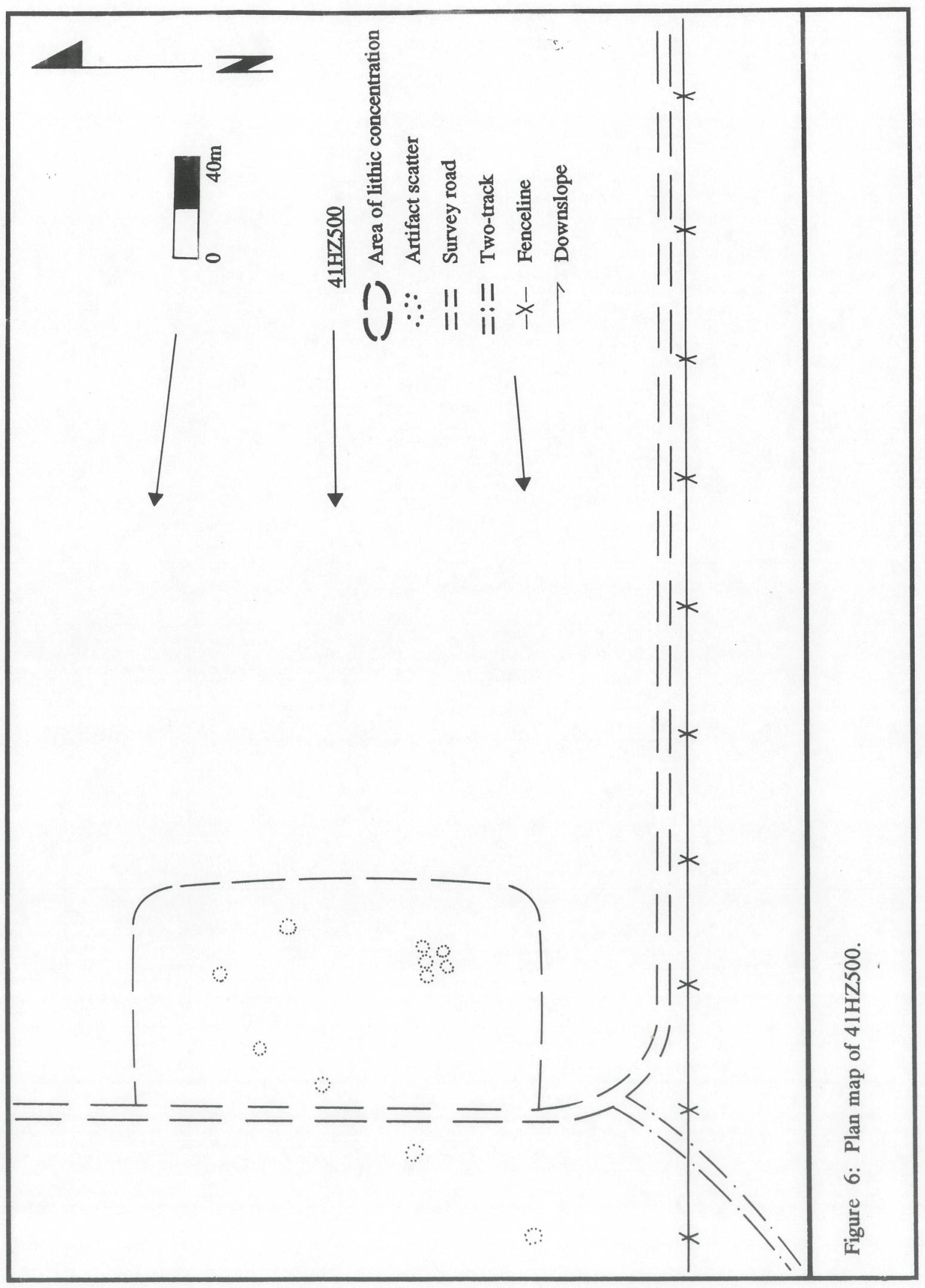




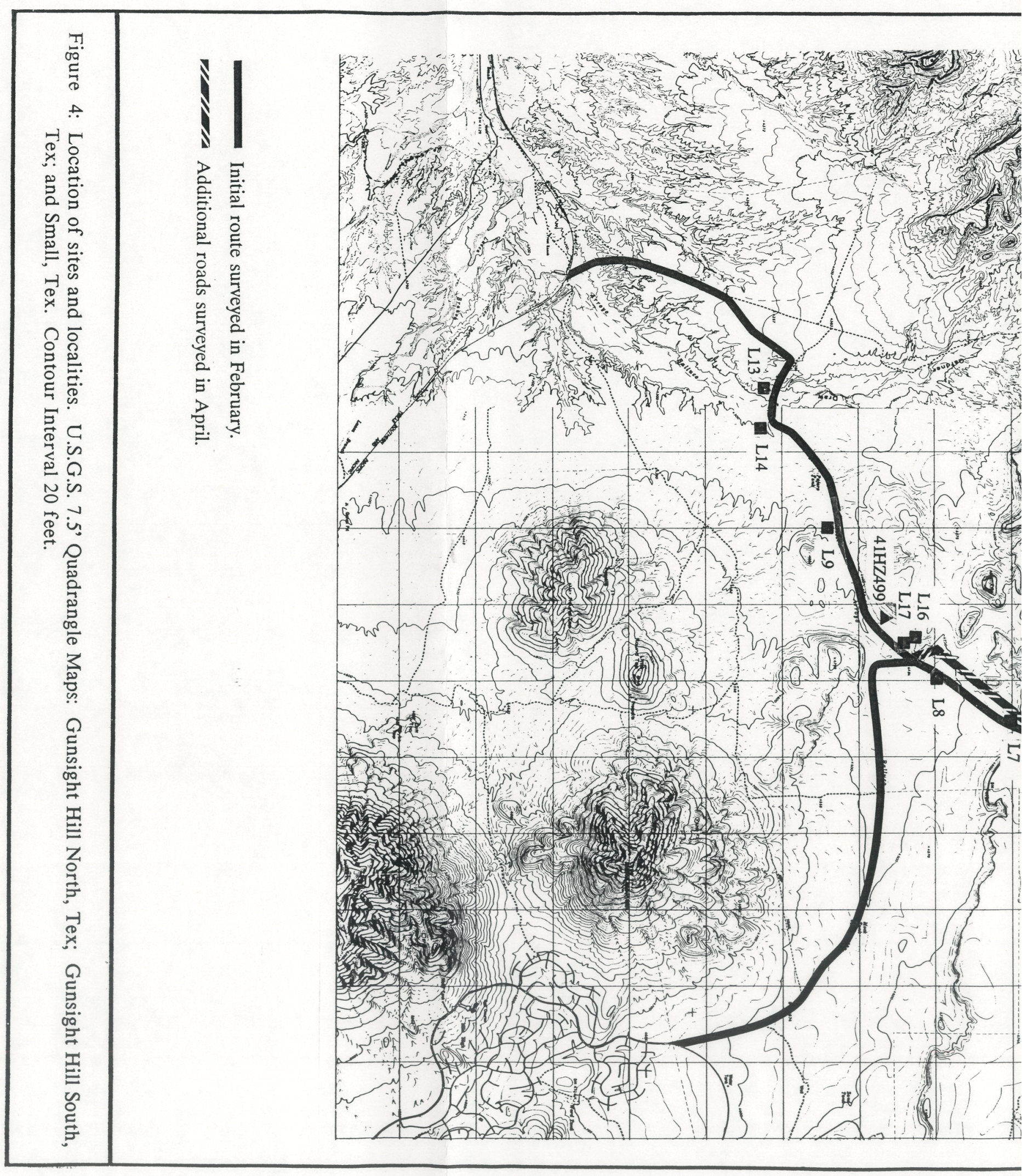


Locality 4: one tertiary, caramel-colored chert flake and one tertiary quartzite flake

Locality 5: one caramel-colored chert flake

Locality 6: mano fragment, material type unknown

Locality 7: one sherd with a reddish-buff interior and exterior and a dark paste with sand temper.

Locality 8: brown chert, cortical flake

Locality 9: one mano of brown quartzite.

Locality 10: one sherd of badly weathered redware.

Locality 11: one mano of sandstone.

Locality 12: $\quad$ purple glass fragment and half a mussel shell.

Locality 13: $\quad$ FCR concentration mixed with unaltered sandstone and quartzite; one meter in diameter; no artifacts in association; thus, unable to determine age.

Locality 14: $\quad$ FCR concentration mixed with unaltered quartzite and sandstone; $0.45 \mathrm{~m}$ in diameter; no artifacts associated with concentration; thus, unable to determine age.

Locality 15: 15 flakes of yellow jasper; some of the flakes retain red cortex. The locality is located $322 \mathrm{~m}$ north of site $41 \mathrm{HZ} 500$.

Locality 16: one sherd with quartzite temper and reddish-brown coloring.

Locality 17: three small sherds, sand temper, of El Paso Brownware.

Locality 18: FCR concentration of sandstone and quartzite; $0.5 \mathrm{~m} \mathrm{x} 0.61 \mathrm{~m}$; no diagnostics associated with concentration; located about $10 \mathrm{~m}$ east of Cheyenne Road.

Locality 19: Two FCR concentrations of sandstone and quartzite; no diagnostics were present at either location. The first concentration measures $0.31 \mathrm{~m}$ square and is located $12 \mathrm{~m}$ west of Cheyenne Road. The second concentration is 0.5 $\mathrm{m}$ square and $13.5 \mathrm{~m}$ west of Cheyenne Road. Additionally, the rocks had been placed over ash, charcoal and burned wood. These FCR concentrations are most likely of recent origin.

\section{Recommendations}

The pedestrian survey was conducted to determine the presence or absence of cultural resources along the proposed route of road improvement near Sierra Blanca, Hudspeth County, Texas. The survey recorded two prehistoric sites, 14 prehistoric localities, one historic locality, and four FCR concentrations of undetermined age. However, the limited nature of a linear survey precludes any firm conclusions concerning the nature of the settlement/subsistence pattern or the actual period of occupation. The low artifact densities exhibited by these sites, however, suggests that the immediate area was not intensively utilized. Such sites apparently functioned as short term foraging camps or specialized extraction sites 
within the larger settlement/subsistence system. Archaic period, Late Prehistoric, and historic period use of the area is reflected by the recorded material of this survey and that of the previous Milehigh survey (Skinner et al. 1973).

The Trans-Pecos area is believed to have been used as a corridor by prehistoric people traveling from the Great Plains to Mexico (Hicks 1989). Little is known of the immediate project area and its relationship to cultural developments in the surrounding region. The discovery of sites with contextual integrity in the area would provide valuable information about activity areas, site utilization, site types, and general information about living conditions and adaptations to the regional environment.

It should be noted that the site areas and the right-of-ways surveyed were heavily impacted by livestock, erosion, deflation, and previous road construction. The topsoil is a shallow, homogenous sandy loam for a depth of at least $40 \mathrm{~cm}$. The contextual integrity of the sites is questionable because of the shallow archeological deposits and deflated landforms. Preliminary testing of the site areas would determine if the sites contain undisturbed deposits which would justify more extensive excavations or if the contextual integrity is so poor that little or no information could be obtained from the sites.

Due to limited subsurface testing of the site areas and the limited archeological investigations in the general area, it is recommended that both sites be protected from any future impacts. Lithic debris, ceramics, and features were observed on the ground surface of the sites. If associated subsurface deposits are present these sites could provide valuable information about site types and artifact assemblages for the region. The limited recording of the geological contexts of the sites, coupled with the limited knowledge of the region's culture history dictates that the National Register-eligibility status of the sites cannot be determined based on the information presently available. Therefore, it is recommended that the National Register eligibility status of sites $41 \mathrm{HZ} 499$ and $41 \mathrm{HZ} 500$ be listed as "unknown" until further subsurface testing can be carried out. These sites (41HZ499, 41HZ500) should be avoided in the future when additional road maintenance activities are conducted. 


\section{REFERENCES}

Alexander, R.K.

1970 Archeological Investigations at Parida Cave, Val Verde County, Texas. Texas Archeological Salvage Project, University of Texas, Austin, 19.

Andretta, A.A

1976 A Single Site Complex on Alpine Creek and Its Implications: A Preliminary Report. In Transactions of the Eleventh Regional Archeological Symposium for Southeastern New Mexico and Western Texas, pp.35-51. Midland Archeological Society. Midland, Texas.

Banks, K.B.

1975 Prehistoric Settlement in the Three-Mile and Sulphur Draw Watersheds. Southern Methodist University, Archaeological Research Program, Research Report 82.

Bearden, S.

1977 Unpublished notes on Evans Heans, an old timer resident of Van Horn, Texas. Van Horn, Texas. Notes on file in Van Horn Project files, Geo-Marine, Inc., Plano, Texas.

Betancourt, J.L.

1981 Preliminary Reconnaissance of Archeological Resources in the Southern Quitman Mountains. In Five Archeological Investigations in the Trans-Pecos Region of Texas, pp. 2782. Texas Antiquities Permit Series No. 6. Texas Antiquities Committee, Austin.

Bousman, C.B. and M. Rohrt

1974 Archeological Reconnaissance of Big Bend National Park. Report prepared for the National Park Service. Archeology Research Program, Southern Methodist University, Dallas.

Bradford, J.E.

1980 Upper Dog Canyon Archeology, Guadalupe Mountains National Park, Texas. Southwest Cultural Resources Center, National Park Service, Santa Fe.

Bryant, V.M., Jr. and R.G. Holloway

1985 A Late-Quaternary Paleoenvironmental Record of Texas: An Overview of the Pollen Evidence, In Pollen Records of Late-Quaternary North American Sediments, edited by V. M. Bryant and R. G. Holloway. American Association of Stratigraphic Palynolosits Foundation, Dallas.

Cliff, M. and Fifield, T.

1980 An Archeological Evaluation of the Floodwater Diversion in the Three-Mile and Sulphur Draw Watershed, Culberson County, Texas. Environmental Consultants, Inc., Dallas.

Coffin, E.F.

1932 Archeological Exploration of a Rock Shelter in Brewster County, Texas. Indian Notes and Monographs 48. Museum of the American Indian, Heye Foundation.

Dering, J.P.

1979 Pollen and Plant Macrofossil Vegetation Record Recovered from Hinds Cave, Val Verde County, Texas. Master's thesis, Department of Anthropology, Texas A\&M University, College Station. 
Edwards, S.K.

1990 Investigations of Late Archaic Coprolites: Pollen and Macrofossil Remains from Hinds Cave (41VV456), Val Verde County, Texas. Unpublished Master's thesis, Department of Anthropology, Texas A\&M University, College Station.

Ford, R.I.

1977 Appendix E. Archeobotany of the Fort Bliss Maneuver Area II, Texas. In Settlement Patterns of the Eastern Hueco Bolson, by M. E. Whalen, pp. 199-206. Submitted to the Corps of Engineers, Albuquerque District, by the El Paso Centennial Museum. Publications in Anthropology No. 4. El Paso Centennial Museum, University of Texas, Austin.

Foster, M.S and J.C. Kelley

1987 Archeological Investigations of Portions of Eight Sites within the Proposed Floodwater Diversion Three-Mile and Sulphur Draw, Three-Mile and Sulphur Draw Watershed, Culberson County, Texas. Jornada Anthropological Research Association, El Paso.

Fox, D.E.

1983 Traces of Texas History: Archeological Evidence of the Past 450 Years. Corona Publishing Company, San Antonio.

Gates, J.S., D.E. White, W.D. Stanley, and H.D. Ackermann

1980 Availability of Fresh and Slightly Saline Groundwater in the Basins of Westernmost Texas. Texas Department of Water Resources, Report 256.

Gerald, R.E.

1978 Report on a Preliminary Archeological Survey of the Revised Location of a Floodwater Diversion in Three-Mile and Sulphur Creeks Watersheds, Culberson County, Texas.

Submitted to Soil Conservation Service, U.S. Department of Agriculture, Temple, Texas.

Gould, F.W.

1969 Texas Plants: A Checklist of Ecological Survey. Texas A\&M Agricultural Experiment Station DUBL. MP-585.

Hedrick, J.A.

1968 Plateau Station Area Survey (EPAS-68). The Artifact 6(1):1-16.

1975 Archeology of the Plateau Site, Culberson County. The Artifact 13(4):45-82.

1986 Five Arrowpoint Types from the Plateau Complex, Van Horn, Texas. Transactions of the Twenty-Second Regional Archeological Symposium for Southeastern New Mexico and Western Texas:15-27.

1988 A Preliminary Report on Archeological Resources in Southern Culberson County in the Vicinity of Van Horn, Texas. Bulletin of the Texas Archeological Society Vol. 59 (1988):129156.

Hicks, P.A.

1989 Environmental Context, Trans-Pecos; Regional Discussion, Trans-Pecos; Early Man in the Southwest, Trans-Pecos; The Unknown Archeology of the Southwest, Trans-Pecos; The Formative Period, Trans-Pecos, Archeological Considerations of the Historic Period, TransPecos. In Human Adaptation and Cultural Change in the Greater Southwest, by A.H. 
Simmons, A.L. Wiener Stodder, D.D. Dykeman, and P.A. Hicks. Arkansas Archeology Survey Research Series No. 32, Wrightsville, Arkansas.

Hoffmann, J., R. Billings, C. Ingram, J. Varnell, and D.E. Peter

1989 Final Environmental Assessment of Valentine Military Operations Area, Texas. Geo-Marine, Inc., Plano, Texas.

Holden, W.C.

1938 Blue Mountain Rock Shelter. Bulletin of the Texas Archeological and Paleontological Society 10:208-221.

1941 Mackenzie Cave and Adjacent Sites in Pecos County. Bulletin of the Texas Archeological and Paleontological Society 13:46-57.

Howard, E.B.

1932 Caves Along the Slopes of the Guadalupe Mountains. Bulletin of the Texas Archeological and Paleontological Society 4:7-19.

Jackson, A.T.

1938 Picture-Writing of Texas Indians. Anthropological Papers Vol. II, and Study No. 27 of the Bureau of Research in the Social Sciences. University of Texas, Austin.

Jenkins, M.E. and A.H. Schroeder

1974 A Brief History of New Mexico. University of New Mexico Press, Albuquerque.

Katz, P.R.

1978 An Inventory and Assessment of Archeological Sites in the High Country of Guadalupe Mountains National Park, Texas. Center for Archeological Research, Archeological Survey Report 36. University of Texas, San Antonio.

Katz, P.R. and P.D.Lukowski

1981 Results of Archeological Survey in the Salt Flat Locality of Northern Hudspeth County, Texas. In Five Archeological Investigations in the Trans-Pecos Region of Texas, Texas Antiquities Committee, pp. 1-26. Texas Antiquities Committee Permit Series No. 6. Texas Antiquities Committee, Austin.

Kelley, J.C.

1952a Factors Involved in the Abandonment of Ceratin Peripheral Southwestern Settlements. American Anthropologist 54(3):356-387.

1952b The Historic Indian Pueblos of La Hunta de los Rios. New Mexico Historical Review 27(4):257-295.

1955 Juan Sabeata and Diffusion in Aboriginal Texas. American Anthropologist 57(5):981-995.

1957 The Livermore Focus: A Clarification. El Palacio 64(1-2):44-52.

1986 Jumano and Patarabueye: Relations at La Hunta de los Rios. Anthropological Papers No. 77. Museum of Anthropology, University of Michigan, Ann Arbor. 
Kelley, J.C., T.N. Campbell, and D.J. Lehmer

1940 Report on the Skeletal Material. In The S.U. Site: Excavations at a Mogollon Village, Western New Mexico, edited by P.S. Martin, pp. 88-93. Field Museum of Natural History Publication 476, Anthropological Series 32(1), Chicago.

Kirkland, F.

1937 A Study of Indian Pictures in Texas. Bulletin of the Texas Archeological and Paleontological Society 9:89-119.

Lehmer, D.J.

1958 A Review of Trans-Pecos Texas Archeology. Bulletin of the Texas Archeological Society 29:109-144.

Lindsay, A.J.

1969 Current Research: Texas. American Antiquity 34(1):103.

Lord, $\mathrm{K}$.

1984 The Zooarchaeology of Hinds Cave, Val Verde County, Texas. Ph.D. dissertation, Department of Anthropology, Texas A\&M University, College Station.

Mallouf, R.J.

1981 Observations Concerning Environmental and Cultural Interactions During the Terminal Pleistocene and Early Holocene in the Big Bend of Texas and Adjoining Regions. Bulletin of the Texas Archeological Society 52:121-146.

1985 A Synthesis of Eastern Trans-Pecos Prehistory. Unpublished Master's thesis, University of Texas, Austin.

1986 Prehistoric Cultures of the Northern Chihuahuan Desert. In Invited Papers From the Second Symposium on Resources of the Chihuahuan Desert Region, edited by J.C. Barlow, A.M. Powell, and B.A. Timmermann, pp. 69-78. Chihuahuan Desert Research Institute, Sul Ross State University, Alpine, Texas.

Marmaduke, W.

1978 Prehistoric Cultures in Trans-Pecos Texas: An Ecological Explanation. Unpublished Ph.D. dissertation, Department of Anthropology, University of Texas, Austin.

Marmaduke, W. and $\mathrm{H}$. Whitsett

1975 An Archeological Reconnaissance in the Central Davis Mountains, Texas. Natural Area Survey. Supplement of Part III of IV. Lyndon B. Johnson School of Public Affairs, University of Texas, Austin.

McMahan, C.A., R.G. Frye, and K.L. Brown

1984 The Vegetation Types of Texas, Including Cropland. (Illustrated synopsis and map). Wildlife Division, Texas Parks and Wildlife Department, Austin.

McNatt, L.

1981 An Archeological Reconnaissance of the Lower Pecos River. In Five Archeological Investigations in the Trans-Pecos Region of Texas, by the Texas Antiquities Committee, pp. 115-167. Texas Antiquities Committee Permit Series No. 6. Texas Antiquities Committee, Austin. 
Mera, H.P.

1938 Reconnaissance and excavations in southeastern New Mexico. Memoirs of the American Anthropological Association 51.

Pool, W.C., E. Triggs, and L. Wren

1975 A Historical Atlas of Texas. Encino Press, Austin.

Poyo, G.E. and G.M. Hinojosa (editors)

1991 Tejano Origins in Eighteenth-Century San Antonio. University of Texas Press, Austin.

Riley, C.L.

1987 The Frontier People: The Greater Southwest in the Protohistoric Period. Unpublished Ph.D. dissertation, University of Washington, Seattle.

Ruecking, F., Jr.

1953 The Economic System of the Coahuiltecans of Southern Texas and Northeastern New Mexico. Texas Journal of Science 6(3):480-497.

1955b The Social Organization of the Coahuiltecan Indians of Southern Texas and Northeastern New Mexico. Texas Journal of Science 7(4):357-388.

Sayles, E.B.

1935 An Archeological Survey of Texas. Medallion Papers No. 17. Gila Pueblo, Globe, Arizona.

1941 Infant Burial in Carrying Basket. Bulletin of the Texas Archeological and Paleontological Society 1:77-87.

Schmidly, D.J.

1977 Mammals of Trans-Pecos Texas. Texas A\&M Press, College Station and London.

Shackelford, W.J.

1955 Excavations at the Polvo Site in Western Texas. American Antiquity 20(3):256-262.

Shafer, H.J.

1977 Art and Territoriality in the Lower Pecos Region, Texas. Plains Anthropologist 22(75):13-22.

Simmons, A.H, A.L. Wiener Stodder, D.D. Dykeman, and P.A. Hicks

1989 Human Adaptation and Cultural Change in the Greater Southwest. Arkansas Archeological Survey Research Series, 32.

Skinner, S.A. and C.B. Bousman

1973 Prehistoric Archeology in the Three-Mile and Sulphur Draw Watershed. Southern Methodist University, Archaeological Research Program, 26. Dallas, Texas

Skinner, S.A., P.P. Steed, Jr., and S.E. Bearden

1973 Prehistory of Milehigh. Southern Methodist University, Archaeology Research Program, 30. Dallas, Texas.

Smith, V.J.

1932 The Relation of the Southwestern Basket Maker to the Dry Shelter Culture of the Big Bend. Bulletin of the Texas Archeological and Paleontological Society 4:55-62. 
1933 Sandals of the Big Bend Culture with Additional Notes Concerning Basket Maker Evidence. Bulletin of the Texas Archeological and Paleontological Society 5:57-65.

1934 Hard Rock Shelter. Bulletin of the Texas Archeological and Paleontological Society 6:97-106.

1938 Carved Rock Shelter. Bulletin of the Texas Archeological and Paleontological Society 10:222233.

Smith, V.J. and J.C. Kelley

1933 The Meriwether Rock Shelter, A Report on a Rock Shelter Excavation in the Big Bend of Texas. West Texas Historical and Scientific Society Circular 3.

Sobolik, K.

1988 The Prehistoric Diet and Subsistence of the Lower Pecos Region, as Reflected in Coprolites from Baker Cave, Val Verde County, Texas. Unpublished Masters thesis, Department of Anthropology, Texas A\&M University, College Station.

Sommer, A.

19741973 SWFAS Early Man Conference. Transactions of the Ninth Regional Archeological Symposium for Southeastern New Mexico and West Texas, pp. 109-141. Midland Archeological Society, Midland, Texas.

Suhm, D.A., A.D. Krieger, and E.P. Jelks

1954 An Introductory Handbook of Texas Archeology. Bulletin of the Texas Archeological Society 20.

Taylor, W.W.

1964 Tethered Nomadism and Water Territoriality: An Hypothesis. Actas y Memorias del XXXV Congreso Internacional de Americanistas, 1962:197-203.

Tyler, R.C.

1975 The Big Bend: A History of the Last Texas Frontier. U.S. Department of the Interior, Washington, D.C.

Whalen, M.E.

1981 An Investigation of Pithouse Village Structure in Western Texas. Journal of Field Archeology 8(3):303-311.

Williams-Dean, G.

1978 Ethnobotany and Cultural Ecology of Prehistoric Man in Southwest Texas. Ph.D. dissertation, Department of Anthropology, Texas A\&M University, College Station.

Winchell, F., G. Brown, M.B. Cliff, and S.K. Edwards

1992 Cultural Resources Monitoring/Survey of a JTF-6 Action, Van Horn, Texas Sector. GeoMarine, Inc., Plano, Texas.

Wylie, R.L.

1973 History of Van Horn and Culberson County, Texas. Pioneer Book Publishers, Inc. Hereford, Texas. 